\title{
Colony-stimulating factor-1 requires PI3-kinase- mediated metabolism for proliferation and survival in myeloid cells
}

\author{
AW-M Lee ${ }^{*, 1}$ and DJ States ${ }^{2}$ \\ 1 Department of Pharmacology, University of Michigan Medical School, 1150W. \\ Medical Center Dr., Ann Arbor, Ml 48109, USA \\ 2 Department of Human Genetics and Program in Bioinformatics, University of \\ Michigan Medical School, Ann Arbor, MI, USA \\ * Corresponding author: AW-M Lee, Department of Pharmacology, The \\ University of Michigan Medical School, 1150 W. Medical Center Dr., Ann Arbor, \\ MI 48109, USA. Tel: 734-647-6004; Fax: 734-647-6202; \\ E-mail: awmlee@umich.edu
}

Received 19.8.05; revised 22.12.05; accepted 17.1.06; published online 03.3.06 Edited by $S$ Kornbluth

\begin{abstract}
Colony-stimulating factor-1 (CSF-1) is essential for macrophage growth, differentiation and survival. Myeloid cells expressing a CSF-1 receptor mutant $(\Delta \mathrm{KI})$ show markedly impaired CSF-1-mediated proliferation and survival, accompanied by absent signal transducers and activators of transcription 3 (Stat3) phosphorylation and reduced PI3kinase/Akt activity. Restoring phosphatidylinositol 3-kinase (PI3-kinase) but not Stat3 signals reverses the mitogenic defect. CSF-1-induced proliferation and survival are sensitive to glycolytic inhibitors, 2-deoxyglucose and 3-bromopyruvate. Consistent with a critical role for PI3-kinase-regulated glycolysis, $\Delta \mathrm{KI}$ cells reconstituted with active PI3-kinase or Akt are hypersensitive to these inhibitors. CSF-1 upregulates hexokinase II (HKII) expression through PI3-kinase, and PI3-kinase transcriptionally activates the HKII promoter. Moreover, HKII overexpression partially restores mitogenicity. In contrast, $\mathrm{Bcl}-\mathrm{x}_{\mathrm{L}}$ expression does not enhance long-term proliferation, although short-term cell death is suppressed in a glycolysis-independent manner. This study identifies robust PI3-kinase activation as essential for optimal CSF-1-mediated mitogenesis in myeloid cells, in part through regulation of HKII and support of glycolysis.

Cell Death and Differentiation (2006) 13, 1900-1914.

doi:10.1038/sj.cdd.4401884; published online 3 March 2006
\end{abstract}

Keywords: colony-stimulating factor-1; macrophage colonystimulating factor; phosphatidylinositol 3-kinase; Akt; hexokinase; glycolysis; metabolism; myeloid; apoptosis

\footnotetext{
Abbreviations: 2-DG, 2-deoxyglucose; BMM, bone marrowderived macrophages; BrPA, 3-bromopyruvic acid; CSF-1, colony-stimulating factor-1; HK, hexokinase; PI3-kinase, phosphatidylinositol 3-kinase
}

\section{Introduction}

The development of hematopoietic progenitor cells is controlled by lineage-specific colony-stimulating factors, which promote functional activation as well as proliferation and survival, counteracting intrinsic cell death programs. The colony-stimulating factor-1 (CSF-1) receptor (CSF-1R), a receptor tyrosine kinase, is expressed in monocytes, macrophages and their myeloid progenitors as well as osteoclasts, trophoblasts and microglia. ${ }^{1}$ Mice lacking CSF-1 (Csf1 ${ }^{o p}$ ) Csf $1^{o p}$ ) or CSF-1R exhibit abnormalities in innate immunity, bone remodeling, male and female fertility and mammary ductal morphogenesis, reflecting the pleiotropic nature of mononuclear phagocytes. They are severely deficient in hematopoietic stem cells and myeloid progenitors. Because of CSF-1's importance in innate immunity, it is advocated as adjunct therapy in severe infections. ${ }^{2}$ Recently, a CSF-1R kinase inhibitor has been developed to target macrophages in disease states such as arthritis, osteoporosis and cancer. ${ }^{3}$ For these reasons, it is essential to understand how CSF-1 supports the proliferation and survival of myeloid lineage cells.

Upon binding, CSF-1 induces CSF-1R tyrosine phosphorylation, leading to the activation of Ras/Erk ${ }^{4}$ and Class $\mathrm{I}_{\mathrm{A}}$ phosphatidylinositol 3-kinase (PI3-kinase) ${ }^{5}$ and to the formation of DNA-binding complexes containing signal transducers and activators of transcription (Stat) $1,3,5 .^{6}$ The CSF-1R also recruits Src kinases via an autophosphorylation site in the juxtamembrane domain. ${ }^{7,8}$ The kinase insert $(\mathrm{KI})$ region in the CSF-1R has binding sites for Grb2/Mona, Stat1 and PI3kinase. $^{9}$ CSF-1-provoked Erk and PI3-kinase activities, however, are not exclusively dependent on these sites: when expressed in the $32 \mathrm{D}$ myeloid progenitor cell line, the $\Delta \mathrm{KI}$ mutant lacking the $\mathrm{KI}$ can still activate Erk and PI3-kinase. It turns out that the $\Delta \mathrm{KI}$ mutant uses an Src-Gab2 pathway to activate PI3-kinase and an Src-Shc-Grb2 pathway to stimulate Ras/Erk. ${ }^{10}$ Much attention has been focused on PI3-kinase as a regulator of cell survival, growth and division owing to the observation that PTEN, a PI3-kinase phosphatase, is frequently mutated in human cancers. The beststudied downstream PI3-kinase effector is the Ser/Thr kinase Akt/PKB. Akt functions as a critical mediator of cell survival through inhibitory phosphorylations of proapoptotic molecules and activation of the NF- $\kappa$ B pathway. ${ }^{11}$ Akt also promotes cell cycle progression and regulates cellular metabolism. For example, basal T-cell metabolism as well as CD28 activation involves an Akt-dependent increase in glycolysis. ${ }^{12}$ Through an unknown mechanism, Akt is also required for maintaining the association of hexokinase (HK) with mitochondria. ${ }^{13}$ Additionally, Akt targets glycogen synthase kinase-3 (GSK3) and promotes protein synthesis via the mTOR pathway. ${ }^{14}$ However, it is unclear which of the many functions ascribed to Akt are operational within a given cell and if Akt is the primary 
mediator of cell growth and survival as has been suggested by many studies using potent, myristoylated Akt (MyrAkt).

A potential role for PI3-kinase in mediating monocyte/ macrophage proliferation and survival has been suggested. ${ }^{15,16}$ In one study, ${ }^{15}$ high doses of the PI3-kinase inhibitor, LY294002, were used to induce apoptosis in monocytes. At the concentrations used, LY294002 can inhibit PI3-kinases other than those belonging to Class $\mathrm{I}_{\mathrm{A}}$ as well as mTOR. Another study made use of bone marrow-derived macrophages (BMMs) from p $85 \alpha-/-$ mice $^{16}$ and observed that CSF-1-mediated DNA synthesis was reduced in these cells. However, interpretation of these data is complicated by the fact that there are multiple PI3-kinase isoforms. Class $1_{\mathrm{A}}$ PI3-kinases are composed of a regulatory subunit $(\mathrm{p} 85 \alpha$, $\mathrm{p} 85 \beta$ or $\mathrm{p} 55 \gamma)$ and a catalytic subunit (p110 $\alpha$ or $\mathrm{p} 110 \beta),{ }^{11}$ all of which are present in macrophages. ${ }^{16,17}$ Any of the regulatory subunits can heterodimerize with any of the catalytic subunits. Under normal conditions, regulatory subunits are in excess over catalytic subunits and exert negative effects on growth factor signaling. ${ }^{18}$ Thus, while insulin-induced Akt activation is modestly decreased in p85 $\alpha-/-$ cells, activation is increased in p85 $\beta-/-$ cells. $^{18}$ Additionally, a p85 mutant that cannot bind p110 can restore some of the missing functions of p85 $\alpha-/-$ cells, indicating that $\mathrm{p} 85 \alpha$ also signals through PI3-kinaseindependent pathways. Lastly, apoptosis was not induced by almost complete elimination of Akt1 and Akt2 in BMMs. ${ }^{19}$ Based on the available literature, it is not clear how important Class $\mathrm{I}_{\mathrm{A}}$ PI3-kinases are for macrophage proliferation and survival.

To assess the role of individual pathways in CSF1-dependent proliferation and survival, we generated mitogenically impaired CSF-1R mutants with defects in specific pathways followed by genetic complementation with downstream effectors. When expressed in myeloid cells, the $\Delta \mathrm{KI}$ mutant was found to be deficient in CSF-1-mediated proliferation and survival, as well as Stat3 phosphorylation and PI3-kinase/Akt activity. PI3-kinase and not Stat3 was the critical CSF-1 target in mitogenesis. Although the modest level of PI3-kinase activity provoked by $\Delta \mathrm{KI}$ contributed towards protection of cells from significant apoptosis, notably, robust PI3-kinase activity was needed to maintain adequate glycolysis and normal proliferation and survival, even in the face of many unperturbed pathways. Evidence is provided for the involvement of HKII, the first rate-limiting enzyme of glycolysis. Our studies identify the metabolic state as a major determinant of myeloid cell growth and survival even in the absence of significant apoptosis.

\section{Results}

\section{A mutant CSF-1R lacking the $\mathrm{KI}(\Delta \mathrm{KI})$ shows reduced CSF-1-dependent proliferation and survival}

The $\Delta \mathrm{KI}$ mutant ${ }^{10}$ lacks binding sites in the $\mathrm{KI}$ for major CSF1R effectors, Grb2, PI3-kinase and Stat1. Early studies found that a similar $\Delta \mathrm{KI}$ mutant expressed in NIH 3T3 fibroblasts showed reduced proliferation. ${ }^{5,20}$ However, only in vitro receptor-associated PI3-kinase activity was examined, as neither Grb2 nor Stat1 was known at the time to bind to the
CSF-1R and PI3-kinase targets have not been identified. Moreover, it is not clear if the same phenotype would be observed in a physiologically more relevant cell type. We addressed these questions using bone marrow-derived, IL-3-dependent 32D myeloid progenitors. These cells lack endogenous CSF-1R and when reconstituted with CSF-1R, recapitulate CSF-1-mediated signaling events observed in macrophages. ${ }^{21}$ We examined the proliferation of $32 \mathrm{D}$ cell lines expressing equivalent numbers of transfected wild-type (WT) or $\Delta \mathrm{KI}$ receptors. In the absence of cytokine, WT cells underwent cell death, and after $48 \mathrm{~h}$, could not be rescued by cytokine re-addition (not shown). Although WT cells grew equally well in CSF-1 or IL-3, CSF-1 supported minimal longterm growth of $\Delta \mathrm{KI}$ cells (Figure 1a). When cellular metabolic activity was assayed by the MTS assay, maximal CSF1 -induced activity occurred at $1 \mathrm{nM}$ for both WT and $\Delta \mathrm{KI}$ cells, but peak activity was reduced in $\Delta \mathrm{KI}$ by $\geqslant 60 \%$, compared to WT cells (Figure 1b).

To determine if the reduction in proliferation was owing to apoptosis, we measured DNA fragmentation by an ELISA assay. In WT cells, CSF-1 was almost as potent as IL-3 in suppressing DNA fragmentation induced by IL-3 withdrawal. In $\Delta \mathrm{KI}$ cells, CSF-1 was less effective, but still able to reduce DNA fragmentation by almost $70 \%$, compared to that observed in its absence (Figure 1c, left). The presence of apoptosis was confirmed by Annexin V staining (Figure 1c, right), and by Hoechst staining and electron microscopy where nuclear condensation was observed (Supplemental Figure S1). Notably electron microscopy did not reveal evidence for necrosis or autophagy. In agreement with the data in Figure 1c, many of the $\Delta \mathrm{KI}$ cells grown in CSF-1 appeared to have normal nuclear morphology. Mitochondrial dysfunction is associated with apoptosis and collapse of the mitochondrial transmembrane potential $\left(\Delta \Psi_{\mathrm{m}}\right)$ is an early sign of dysfunction. ${ }^{22}$ Similar to the other data obtained, there was only a modest increase in the percent of $\Delta \mathrm{KI}$ cells showing diminished $\Delta \Psi_{\mathrm{m}}$ when grown in CSF-1 compared to IL-3 (Supplemental Figure S1c).

The above results suggest that apoptosis alone may not entirely account for the $\Delta \mathrm{KI}$ mitogenic defect. We next examined the role of cell cycle progression. Analysis of DNA content showed that in the presence of CSF-1, 25\% of $\Delta \mathrm{KI}$ cells were in the $\mathrm{S}+\mathrm{G}_{2} / \mathrm{M}$ phase compared to $36 \%$ of WT cells (Table 1a). Additionally, BrdU uptake confirmed a $50 \%$ reduced capacity of $\Delta \mathrm{KI}$ cells to synthesize DNA in response to CSF-1 (Table 1b). These results demonstrate that the $\mathrm{KI}$ region in the CSF-1R is necessary for promoting maximal proliferation and protection against apoptosis in myeloid cells.

\section{CSF-1-dependent mitogenesis requires both Erk and PI3-kinase but not Stat3}

Although the Grb2 and PI3-kinase binding sites in the $\mathrm{KI}$ are missing in the $\Delta \mathrm{KI}$ mutant, Erk and PI3-kinase are still activated via Src-dependent mechanisms. ${ }^{10}$ The finding that $\Delta \mathrm{KI}$ has a mitogenic defect prompted us to re-examine the role of Erk and PI3-kinase in CSF-1-induced mitogenesis. Previously, we showed that CSF-1-induced Akt activation is PI3-kinase-dependent in WT cells and can be used as a 

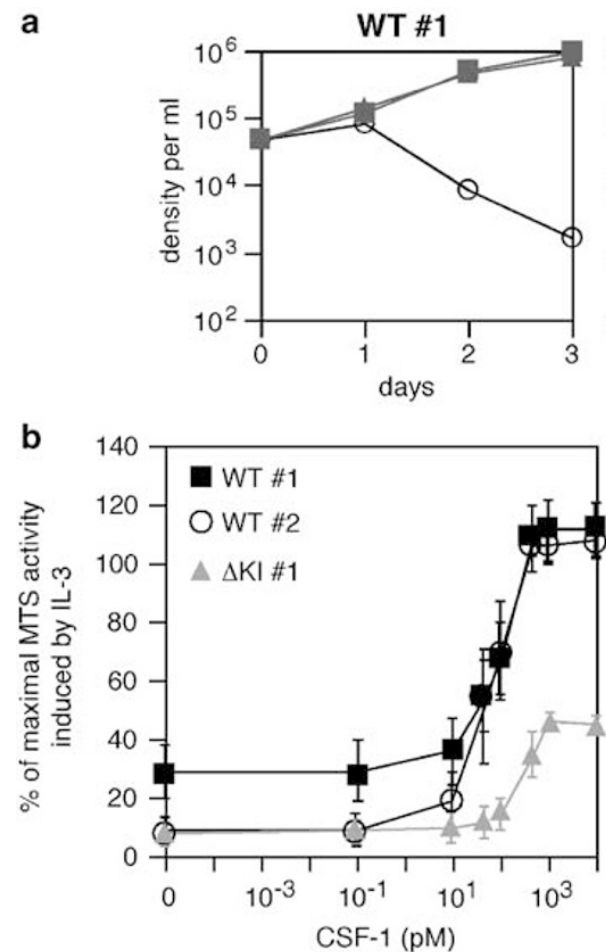
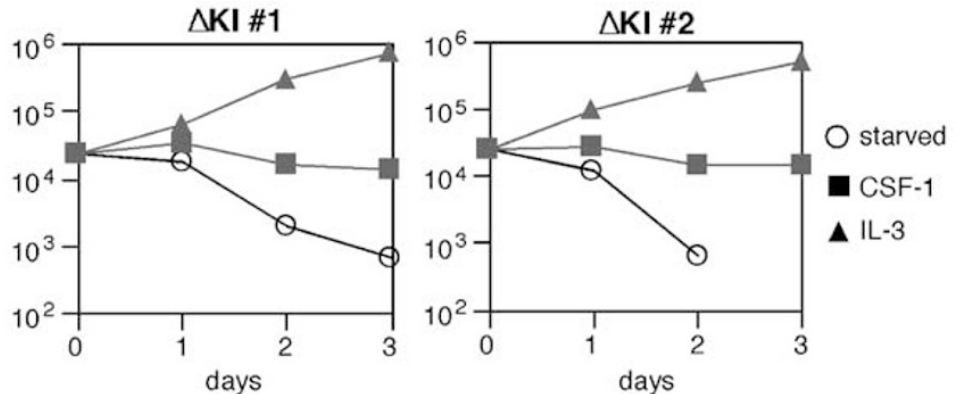

c

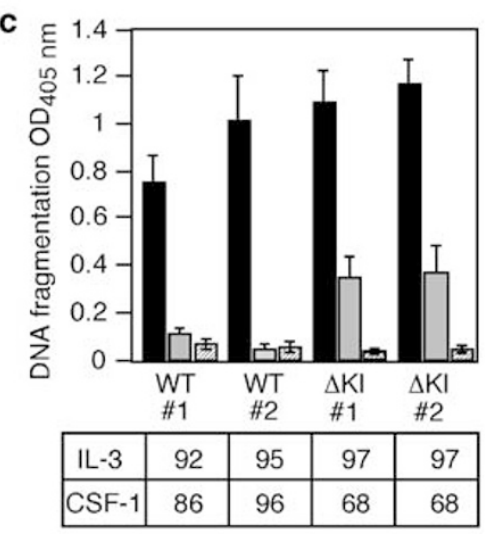

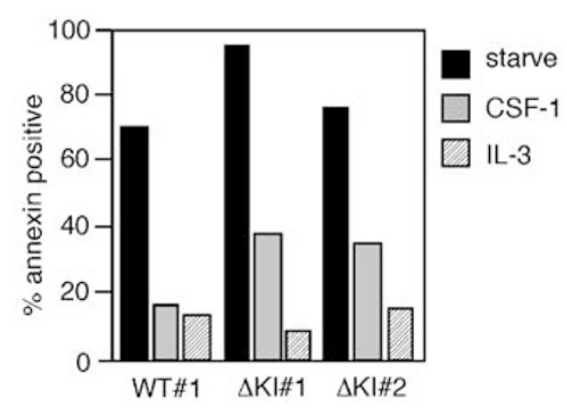

\begin{tabular}{|l|l|l|l|}
\hline IL-3 & 81 & 91 & 80 \\
\hline CSF-1 & 77 & 60 & 54 \\
\hline
\end{tabular}

Figure 1 CSF-1-dependent mitogenesis and survival. (a) WT or $\Delta \mathrm{KI}$ clones were plated at $5 \times 10^{4} / \mathrm{ml}$ without or with CSF-1 or IL-3 and viable cell numbers determined. Representative data of at least three experiments are shown. (b) Cells were plated at $2 \times 10^{5} / \mathrm{ml}$ and analyzed $48 \mathrm{~h}$ later. MTS activity in the presence of CSF-1 is plotted as a percent of that observed in IL-3 (means \pm S.D., $n$, number of experiments $=6$ ). (c) (Left) DNA fragmentation was measured after $36 \mathrm{~h}$ in the culture conditions shown. Plotted are the means \pm S.D. $(n=3)$. (Right) Annexin $V$ staining under the same conditions is shown as a percent of total population. Numbers under both panels refer to the percent suppression relative to starvation conditions

Table 1 Cell cycle analysis: (a) DNA content by propidium iodide staining ${ }^{\mathrm{a}}$ and (b) BrdU incorporation ${ }^{\mathrm{b}}$

\begin{tabular}{|c|c|c|c|c|c|c|c|c|}
\hline \multirow[b]{2}{*}{ Condition } & \multicolumn{3}{|c|}{ WT } & \multicolumn{3}{|c|}{$\Delta \mathbf{K I}$} & & \\
\hline & Sub-G $\mathbf{G}_{1}$ & $G_{0} / G_{1}$ & $\mathrm{~S}+\mathrm{G}_{2} / \mathrm{M}$ & Sub-G $\mathbf{G}_{1}$ & $G_{o} / G_{1}$ & $\mathrm{~S}+\mathrm{G}_{2} / \mathrm{M}$ & & \\
\hline \multicolumn{9}{|c|}{ (a) DNA content by propidium iodide staining } \\
\hline \multirow{4}{*}{$\begin{array}{l}\text { Starved } \\
\text { CSF-1 } \\
\text { IL-3 }\end{array}$} & $38 \pm 7$ & $44 \pm 7$ & $18 \pm 2$ & $44 \pm 9$ & $40 \pm 6$ & $16 \pm 3$ & & \\
\hline & $13 \pm 7$ & $51 \pm 9$ & $36 \pm 3$ & $21 \pm 9$ & $54 \pm 8$ & $25 \pm 3$ & & \\
\hline & $8 \pm 7$ & $54 \pm 10$ & $38 \pm 4$ & $8 \pm 9$ & $55 \pm 16$ & $37 \pm 8$ & & \\
\hline & \multicolumn{4}{|c|}{ WT } & \multicolumn{4}{|c|}{$\Delta \mathbf{K I}$} \\
\hline Condition & Sub-G 1 & $G_{0} / G_{1}$ & s & $\mathrm{G}_{2} / \mathrm{M}$ & Sub-G & $\mathrm{G}_{\mathrm{o}} / \mathrm{G}_{1}$ & $\mathbf{S}$ & $\mathrm{G}_{2} / \mathrm{M}$ \\
\hline \multicolumn{9}{|c|}{ (b) BrdU incorporation } \\
\hline Starved & 2.7 & 60.9 & 25.2 & 11.2 & 1.4 & 70.7 & 10.9 & 17.0 \\
\hline CSF-1 & 2.3 & 29.0 & 63.1 & 5.6 & 1.6 & 55.1 & 34.8 & 8.6 \\
\hline IL-3 & 3.2 & 23.2 & 70.1 & 3.6 & 1.3 & 22.9 & 72.7 & 3.1 \\
\hline
\end{tabular}

${ }^{\mathrm{a} C}$ Cells were starved of cytokines for $8 \mathrm{~h}$ before the addition or not of CSF-1 $(10 \mathrm{nM})$ or IL-3 $(200 \mathrm{U} / \mathrm{ml})$. They were incubated for an additional $20 \mathrm{~h}$ and processed for cell

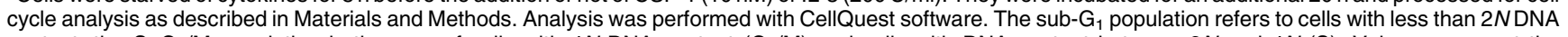
content; the $S+G_{2} / M$ population is the sum of cells with $4 N$ DNA content $\left(G_{2} / M\right)$ and cells with DNA content between $2 N$ and $4 N(S)$. Values represent the means + S.D. $(n=4)$. The difference in the CSF-1-treated $\mathrm{S}+\mathrm{G}_{2} / \mathrm{M}$ populations between $\mathrm{WT}$ and $\Delta \mathrm{Kl}$ is significant $(P=0.006)^{\mathrm{b}}$ Cells were processed as described in (a). BrdU was added during the last hour of incubation. Cells were then processed for double staining with anti-BrdU-FITC and 7-AAD (see Materials and Methods) and analyzed by flow cytometry. Bivariate analysis was performed with CellQuest software to discriminate between cell subsets based on total DNA and incorporated BrdU levels. Data for one out of two independent experiments are shown. Note that the staining procedure is likely to underestimate the fraction of cells with sub- $\mathrm{G}_{1}$ DNA as the cells were permeabilized with a buffer containing saponin (BD Biosciences)

readout for PI3-kinase activity. ${ }^{10}$ We also reported that CSF-1 could activate Akt in $\Delta \mathrm{KI}$ cells, but did not quantify the difference, if any, in comparison to WT cells. Here, we demonstrate that the intensity of CSF-1-mediated Akt activa- tion was reduced by two to five-fold in $\Delta \mathrm{KI}$ cells when compared to WT cells over the entire course of induction (Figure 2a). Thus, the Src-Gab2 pathway ${ }^{10}$ is not sufficient to maximally activate PI3-kinase and direct p85 binding to the $\mathrm{KI}$ 
a

\begin{tabular}{|c|c|c|c|c|c|c|}
\hline \multicolumn{2}{|r|}{$0 \mathrm{~min}$} & $2 \mathrm{~min}$ & $5 \min$ & $15 \mathrm{~min}$ & $30 \mathrm{~min}$ & $60 \mathrm{~min}$ \\
\hline WT & $\Delta \mathrm{KI}-1 \quad \mathrm{AKI}-2$ & WT $\triangle \mathrm{KKl}-1 \quad \mathrm{AKI}-2$ & WT $\triangle K \mathrm{Kl}-1 \Delta \mathrm{Kl}-2$ & $\overline{W T} \quad \Delta K \mathrm{Kl}-1 \quad \Delta \mathrm{KI}-2$ & $\overline{W T} \quad \Delta K \mathrm{Kl}-1 \mathrm{AKI}-2$ & $\begin{array}{llll}\text { WT } & \Delta K \mathrm{KI}-1 & \Delta K \mathrm{KI}-2\end{array}$ \\
\hline & & $\longrightarrow$ & $-\cdots$ & $--\cdots$ & $-\cdots$ & 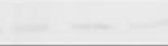 \\
\hline & & & IB: $\alpha \mathrm{pA}$ & kt(T308) & & \\
\hline
\end{tabular}

IB: $\alpha$ Akt

b

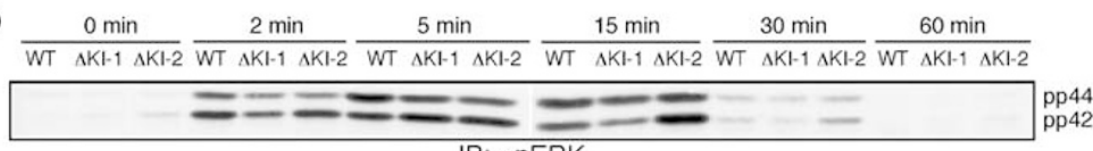

IB: $\alpha$.pERK

IB: $\alpha$ ERK
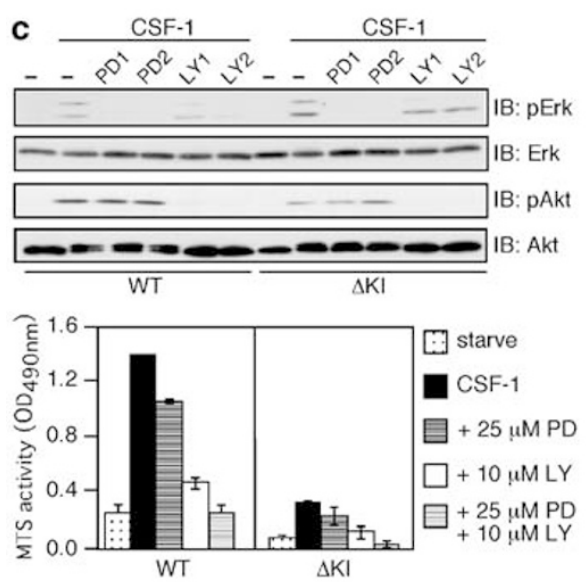

d
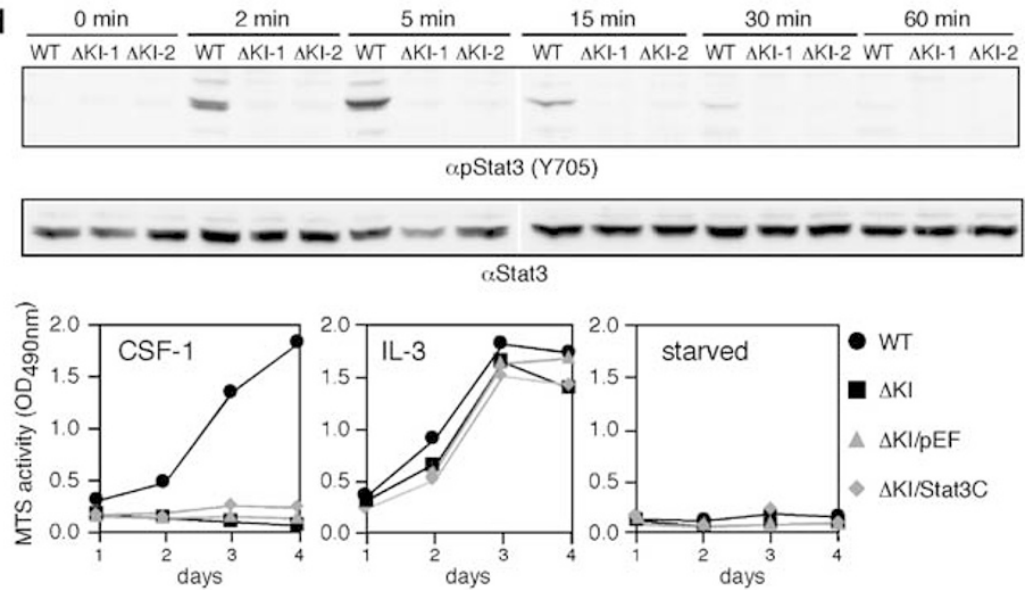

Figure 2 PI3-kinase, and less so, Erk, but not Stat3, are critical for CSF-1-mediated mitogenesis. (a) (Left) Cell lysates were prepared from starved and CSF-1stimulated cells at the indicated times and immunoblotted (IB) sequentially with $\alpha$-pAkt (T308) and $\alpha$-Akt. (Right) The panel shows the means \pm S.D. ( $n=3$ ) for each time, represented as the percent of CSF-1-induced pAkt measured at $2 \mathrm{~min}$. (b) Cells were processed as in (a) and lysates blotted as indicated. (c) (Top) Cells were treated as indicated and subjected to immunoblotting. PD1: $25 \mu \mathrm{M}$; PD2: $50 \mu \mathrm{M}, \mathrm{LY} 1: 10 \mu \mathrm{M}$, LY2: $20 \mu \mathrm{M}$. (Bottom) Cells were plated \pm PD98059 (PD) or LY294002 (LY) before adding CSF-1 and analyzed $48 \mathrm{~h}$ later for MTS activity. The amount of DMSO was equalized in all samples. Results are the means \pm S.D. ( $n=3$ ). (d) (Top and middle) Lysates prepared at the indicated times after CSF-1 addition were probed with anti-pStat3 (Y705) or anti-Stat3. (Bottom) WT, $\Delta \mathrm{KI}$ clones and $\Delta \mathrm{KI}$ clones reconstituted with vector (pEF) or constitutively active Stat3 (Stat3C) were incubated in 10\% FBS only (starved) or supplemented with CSF-1 or IL-3. The MTS assay was carried out daily as described in Figure 1. One of three experiments is shown

is also required. Another major player in cell proliferation is mTOR whose targets, $4 \mathrm{E}-\mathrm{BP} 1$ and $\mathrm{p} 70^{\mathrm{S} 6 \mathrm{~K}}$, control translation. ${ }^{14}$ Compared to WT cells, CSF-1-induced phosphorylation of $\mathrm{p} 70^{\mathrm{S} 6 \mathrm{~K}}$ and $4 \mathrm{E}-\mathrm{BP} 1$ was largely preserved in $\Delta \mathrm{KI}$ cells (Supplemental Figure S2a). Additionally, we observed no significant difference between WT and $\Delta \mathrm{KI}$ cells in CSF-1stimulated Erk (Figure 2b), JNK (Supplemental Figure S2b) or Rac activity (Supplemental Figure S2c).

Chemical inhibitors were used to further examine the contribution of PI3-kinase and Erk to mitogenesis. We confirmed that the concentrations of the MEK inhibitor, PD98059 (PD), and the PI3-kinase inhibitor, LY294002 (LY), used in our experiments could completely prevent CSF-1induced Erk and Akt activation, respectively (Figure 2c, top). PD or LY treatment reduced CSF-1's ability to support MTS activity (Figure 2c, bottom) with LY exerting a more potent effect. Notably, a combination of PD and LY completely suppressed CSF-1-stimulated mitogenesis in both WT and $\Delta \mathrm{KI}$ cells. Thus, PI3-kinase and, less so, Erk are essential for
CSF-1-induced mitogenesis. As $\Delta \mathrm{KI}$ cells showed a reduced ability to proliferate in CSF-1, and PI3-kinase but not Erk is suboptimally activated, the data suggest that the mitogenic defect is owing to decreased PI3-kinase activation.

CSF-1 stimulates the DNA-binding activity of Stats. ${ }^{6}$ Stat tyrosine phosphorylation is required for dimerization, nuclear translocation and transcriptional activation. ${ }^{23}$ In WT cells, CSF-1 stimulated the tyrosine phosphorylation of Stat1 minimally and that of Stat3 and Stat5 strongly (data not shown). Although Stat5 was equally phosphorylated in WT and $\Delta \mathrm{KI}$ cells (Supplemental Figure S3a), Stat3 phosphorylation was observed in WT but not $\Delta \mathrm{KI}$ cells (Figure 2d, top). To rule out the possibility that absent Stat3 activation also contributed to the proliferative defect of $\Delta \mathrm{KI}$, a constitutively active Stat3, Stat3C, ${ }^{24}$ was expressed from a bicistronic vector in $\Delta \mathrm{KI}$ cells and mass populations analyzed. Full transcriptional activity of $S$ tat 3 requires phosphorylation at $\mathrm{Tyr}$ 705 and Ser $727 .{ }^{23}$ Stat $3 \mathrm{C}$ was dually phosphorylated in $\Delta \mathrm{KI} /$ Stat3C cells (Supplemental Figure S3b), but Stat3C had only 
a modest effect on the ability of CSF-1 to induce MTS activity (Figure 2d, bottom). Thus, expressing an active Stat3 did not correct the $\Delta \mathrm{KI}$ phenotype. In addition, Stat3C expression did not abrogate growth factor dependence and had no effect on IL-3-dependent growth, similar to what was previously reported for bone marrow cells. ${ }^{25}$

\section{A 'stabilized' PI3-kinase expressed in $\Delta \mathrm{KI}$ cells is substantially able to restore CSF-1-dependent mitogenesis}

To determine if the reduction in PI3-kinase activity is responsible for $\Delta \mathrm{Kl}$ 's poor performance as a transducer of growth and survival signals, we stably expressed $\mathrm{p} 110^{*}$ in $\Delta \mathrm{KI}$ cells. In $\mathrm{p} 110^{*}$, the iSH2 domain of $\mathrm{p} 85 \alpha$ is fused to the $\mathrm{N}$-terminus of $\mathrm{p} 110 \alpha,{ }^{26}$ thus stabilizing monomeric $\mathrm{p} 110$ against thermal denaturation at $37^{\circ} .{ }^{27}$ Its in vivo activity is much weaker than the membrane-localizing forms, ${ }^{26}$ but is ideally suited for our purpose, which was to use $\mathrm{p} 110^{*}$ to augment PI3-kinase activity in $\Delta \mathrm{KI}$ cells stimulated by CSF-1. Four independent $\Delta \mathrm{KI}$ clones transfected with $\mathrm{p} 110^{*}$ were selected for further analysis. The p110* expression levels in these clones ranged from two-fold higher to 10 -fold lower than endogenous p110 (Figure 3a). p110* did not abrogate growth factor dependence (Figure $3 \mathrm{~b}$ ), but in the presence of CSF-1, restored to a large degree, long-term mitogenesis to $\Delta \mathrm{KI}$, in a manner dependent on $\mathrm{p} 110^{*}$ levels. In $\Delta \mathrm{KI} / \mathrm{p} 110^{*}$ clones, Akt activation remained CSF -1 inducible, as measured by T308 and $S 473$ phosphorylation; the effect of $p 110^{*}$ was to enhance both the intensity and duration of CSF-1-mediated Akt phosphorylation without affecting Akt expression (Figure 3c). Consistent with the absence of specific activating motifs in p110*, basal Akt activity was marginally enhanced. We hypothesize that in the absence of CSF-1, the level of PI3kinase products generated by $\mathrm{p} 110^{*}$ was not sufficient to induce significant downstream effects, but added to that provoked by CSF-1 resulted in augmented PI3-kinase signaling. The mitogenic-promoting effect of $\mathrm{p} 110^{*}$ was completely reversed by wortmannin, a PI3-kinase inhibitor (Figure 3d) and by LY294002 (not shown), demonstrating that the $\Delta \mathrm{KI}$ rescue was owing to enhanced PI3-kinase activity. Thus, increasing CSF-1-induced PI3-kinase/Akt activity, in the context of other CSF-1-dependent pathways, is sufficient to substantially restore mitogenesis to $\Delta \mathrm{KI}$ cells.

\section{Active Akt partially but significantly recapitulates p110*'s ability to restore mitogenesis to $\Delta \mathrm{KI}$}

Akt is a major PI3-kinase effector. We asked if active Akt could rescue the mitogenic defect of $\Delta \mathrm{KI}$ cells. The E40K mutation in the pleckstrin homology domain enhances the affinity for $\mathrm{PIP}_{3}$ while retaining growth factor inducibility. ${ }^{28} \Delta \mathrm{KI}$ cells were retrovirally transduced with pMSCV-IRES-GFP vectors encoding WT-Akt, E40K-Akt or a kinase-dead (K179M) Akt, and GFP-positive mass populations isolated by cell sorting. We compared the activation of targets downstream of PI3-kinase/ Akt in p110*- and E40K-expressing cells. $\Delta \mathrm{KI} / \mathrm{E} 40 \mathrm{~K}$ cells showed a small increase in basal Forkhead phosphorylation and enhanced and sustained levels upon CSF-1 stimulation (Figure $3 e$ ). Moreover, the levels were similar in $\Delta \mathrm{KI} / \mathrm{p} 110^{*}$ and $\Delta \mathrm{KI} / \mathrm{E} 40 \mathrm{~K}$ cells. E40K similarly enhanced GSK3 phosphorylation, another well-characterized downstream target of Akt, but did not affect basal or CSF-1-induced Erk phosphorylation. In terms of long-term growth, MTS activity, cell number increases and cell viability of $\Delta \mathrm{KI} / \mathrm{E} 40 \mathrm{~K}$ cells were $>50 \%$ of that measured for $\Delta \mathrm{KI} / \mathrm{p} 110^{*}$ cells during the first few days of culture in CSF-1. Notably, the difference between the two cell lines became more prominent after longer periods in culture (Figure 3f). It is possible that there are Akt targets other than Forkhead and GSK3 that are more strongly activated by $\mathrm{p} 110$ * compared to E40K. Additionally, we cannot exclude involvement of a PI3-kinase-dependent but Akt-independent pathway. $\mathrm{K} 179 \mathrm{M}-\mathrm{Akt}$ expression in $\Delta \mathrm{KI}$ cells accelerated cell death, supporting the data in Figure $3 \mathrm{c}$ that the residual PI3kinase activity in $\Delta \mathrm{KI}$ cells is still important for cell proliferation and survival.

\section{Caspase inhibition or $\mathrm{BCl}-\mathrm{x}_{\mathrm{L}}$ overexpression corrects the apoptotic but not mitogenic defect of $\Delta \mathrm{KI}$ cells}

Compared to WT cells, $\Delta \mathrm{KI}$ cells in the presence of CSF-1 undergo accelerated apoptosis (Figure 1c). Although DNA fragmentation is thought to be mediated by caspase-3-like activities, in CSF-1-supported $\Delta \mathrm{KI}$ cells, surprisingly, we detected only trace levels of active caspase-3 and cleaved PARP, a caspase substrate. This is most likely because of protection by the Erk and PI3-kinase pathways (Supplemental Figure S4). The data, therefore, suggest that even low levels of caspase activity can induce DNA fragmentation. In support of this, treatment with a broad-spectrum caspase inhibitor, z-VAD-fmk, reduced DNA fragmentation by $80 \%$ in both starved and CSF-1-treated $\triangle \mathrm{KI}$ cells (Figure $4 \mathrm{a}$, left). However z-VAD-fmk had no effect on CSF-1-mediated MTS metabolism (Figure 4a, right), indicating that caspasemediated apoptosis is probably not the cause of death of $\Delta \mathrm{KI}$ cells. Myeloid cells including $32 \mathrm{D}$ have large numbers of azurophilic granules filled with proteases that are also secreted, necessitating the use of higher than normal doses

Figure 3 Complementation with $\mathrm{p} 110^{*}$ restores long-term CSF-1-dependent growth to $\Delta \mathrm{KI}$ cells. (a) Lysates from $\Delta \mathrm{KI}$ cells or clones of $\Delta \mathrm{KI}$ reconstituted with $\mathrm{p} 110^{*}$ were immunoblotted with anti-p110 $\alpha$. (b) (Left and middle) Cells were seeded at $3 \times 10^{4} / \mathrm{ml}$ and MTS activity determined. This is a representative experiment out of 2 . (Right) The means \pm S.D. $(n=6)$ of day 2 MTS activity for cells cultured in CSF-1 are shown as percentages of that in IL-3. (c) Cell lysates were immunoblotted as shown. This is one of at least three similar experiments. (d) Viable cell numbers were determined in the presence of CSF-1 + wortmannin. (e) Lysates from $\Delta \mathrm{KI}$ clones, either parental or reconstituted with the indicated proteins, were prepared at various times after CSF-1 treatment and immunoblotted as shown. Total Erk levels were used to indicate equal loading. (f) Plots for daily MTS activities (left), viable cell numbers (middle) and percent viabilities (right) are shown for $\Delta \mathrm{Kl} 1 \mathrm{land}$ its derivatives. The break in the abscissa refers to cell passage after 3 days and resumption of analysis 2 days later. Data are not shown for $\Delta \mathrm{KI}, \Delta \mathrm{KI} / \mathrm{MSCV}, \Delta \mathrm{KI} / \mathrm{WT}$-Akt and $\Delta \mathrm{KI} / \mathrm{KD}$ Akt after day 3 as there were no viable cells present and hence off scale. Similar results were obtained for $\Delta \mathrm{KI} \# 2$ and its derivatives. Error bars for MTS activities refer to the means \pm S.D. of triplicates 
a

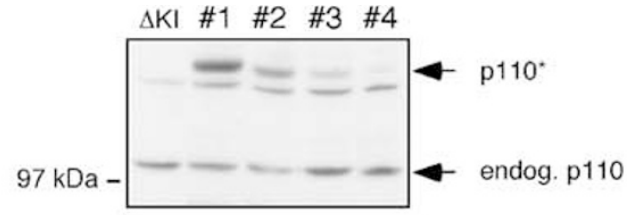

IB: $\alpha \mathrm{p} 110$

b
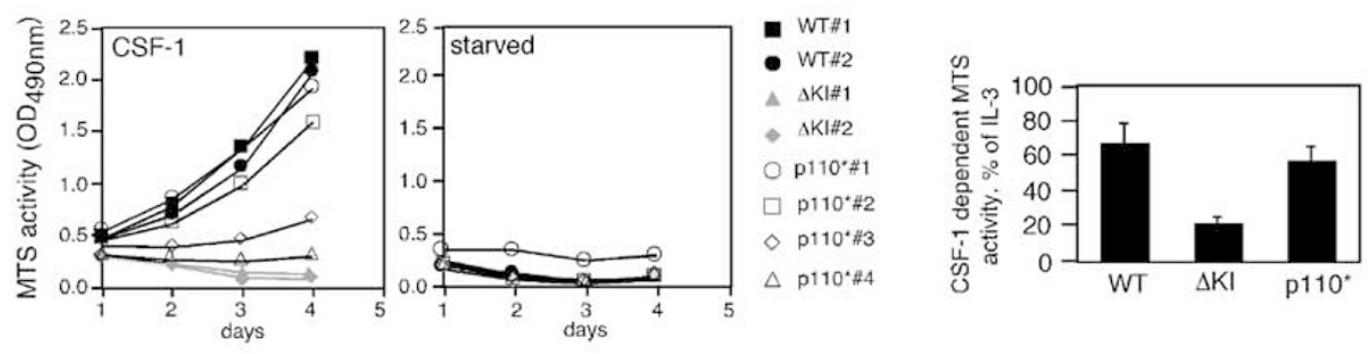

C

WT

$\Delta \mathrm{KI} \# 1$

p110*\#1

p110* \#2

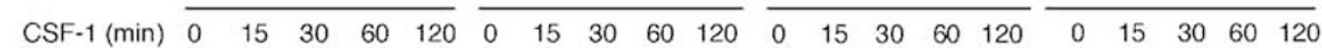

IB: $\alpha$ Akt (T308) $\longrightarrow-\infty-\infty$

IB: $\alpha$ Akt (S473)

$\mathrm{IB}: \alpha \mathrm{Akt} \longrightarrow-\ldots-\ldots-\cdots-\cdots$

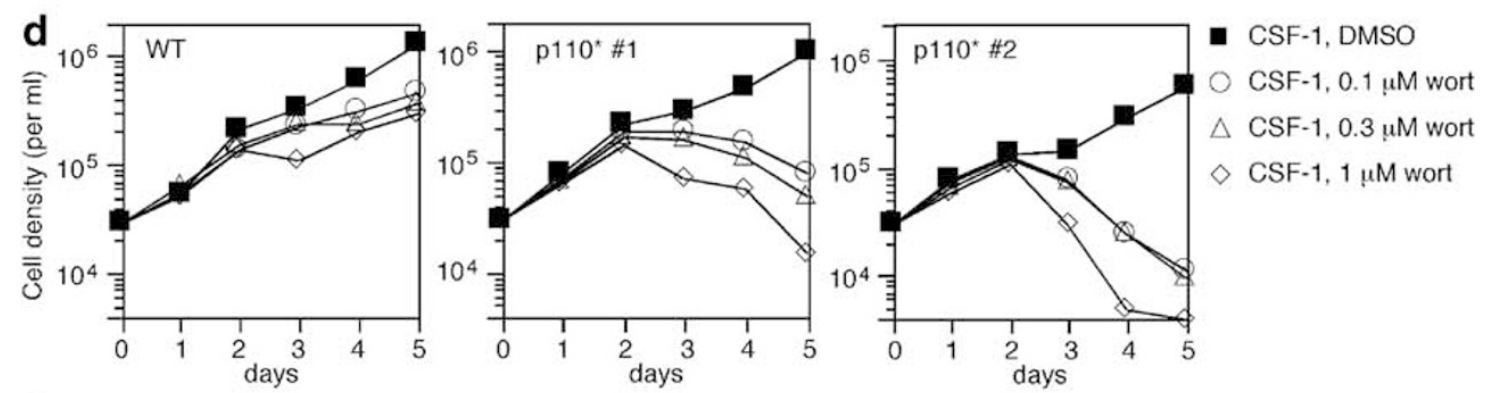

e
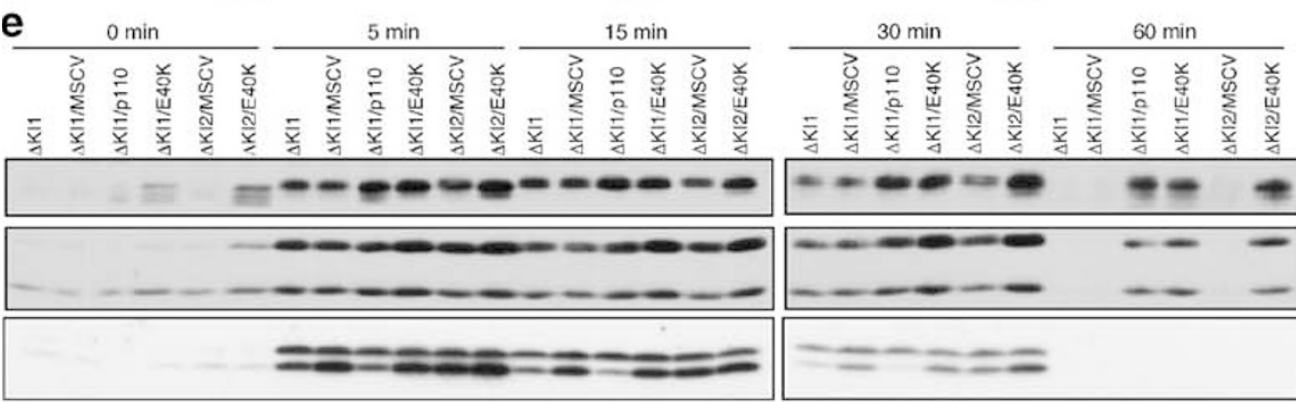

IB: apFKHRL

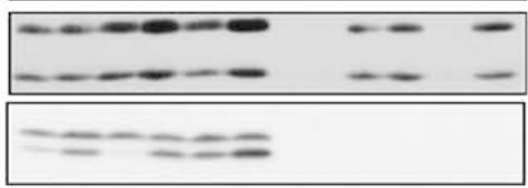

IB: $\propto$ pGSK3

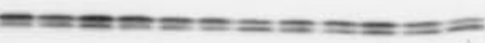

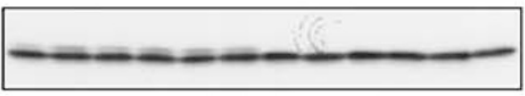

IB: upErk

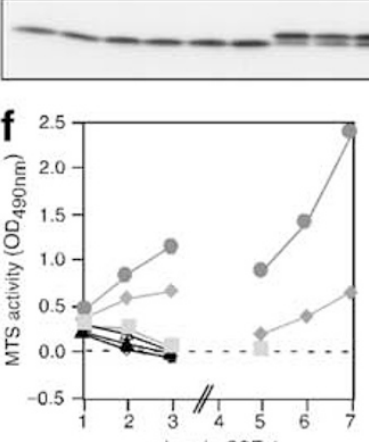

days in CSF-1
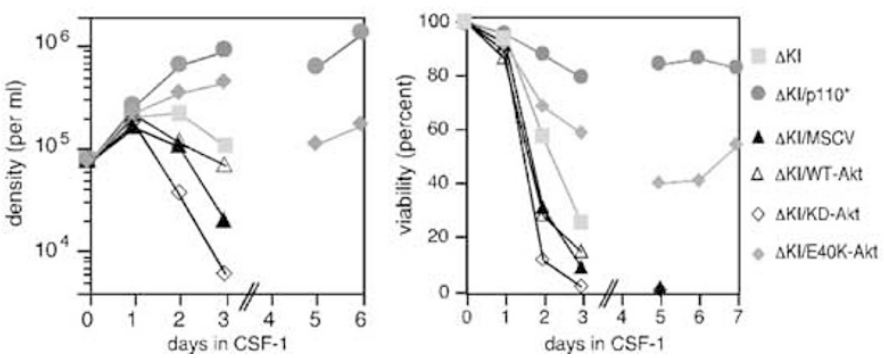

IB: $\alpha$ Erk 
a

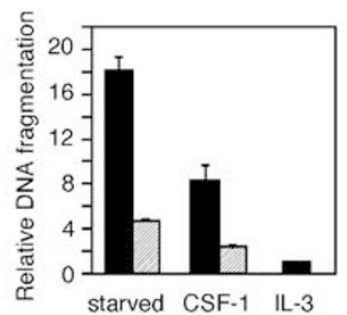

b
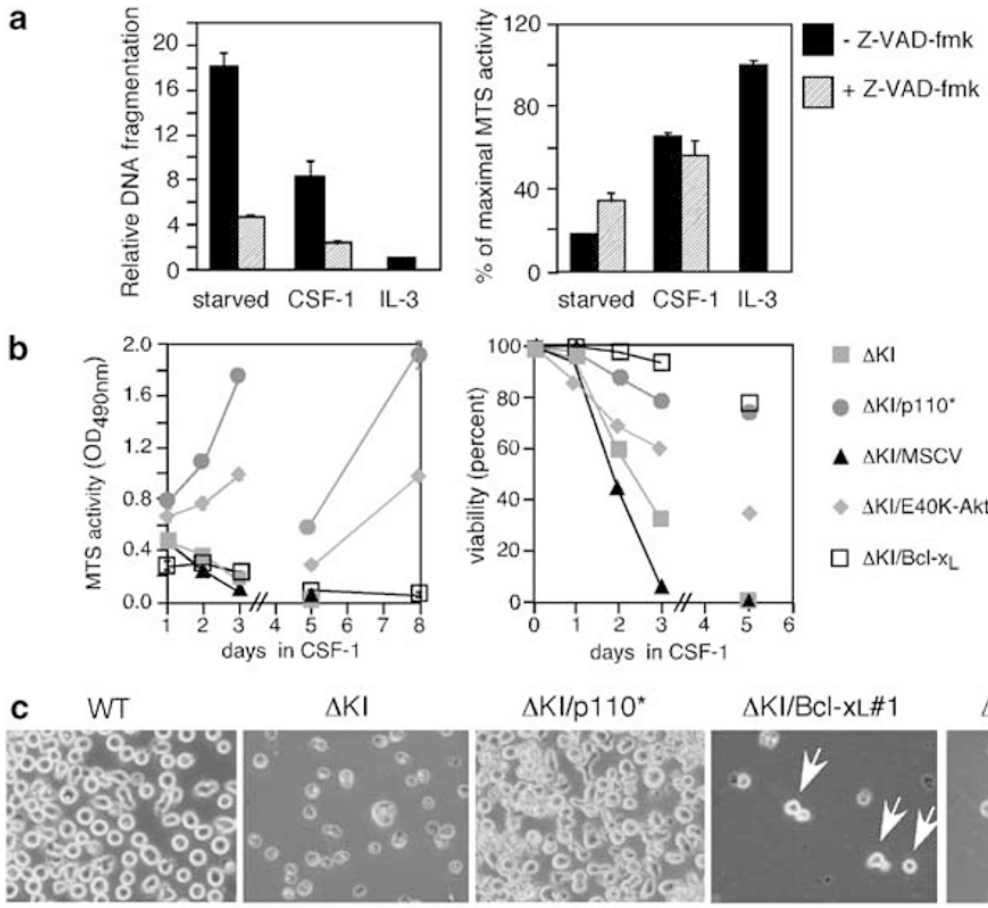

$\Delta \mathrm{Kl} / \mathrm{p} 110^{*}$

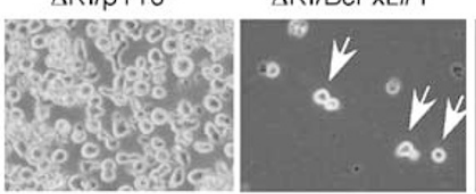

$\Delta \mathrm{KI} / \mathrm{Bcl}-\mathrm{xL} \# 2$
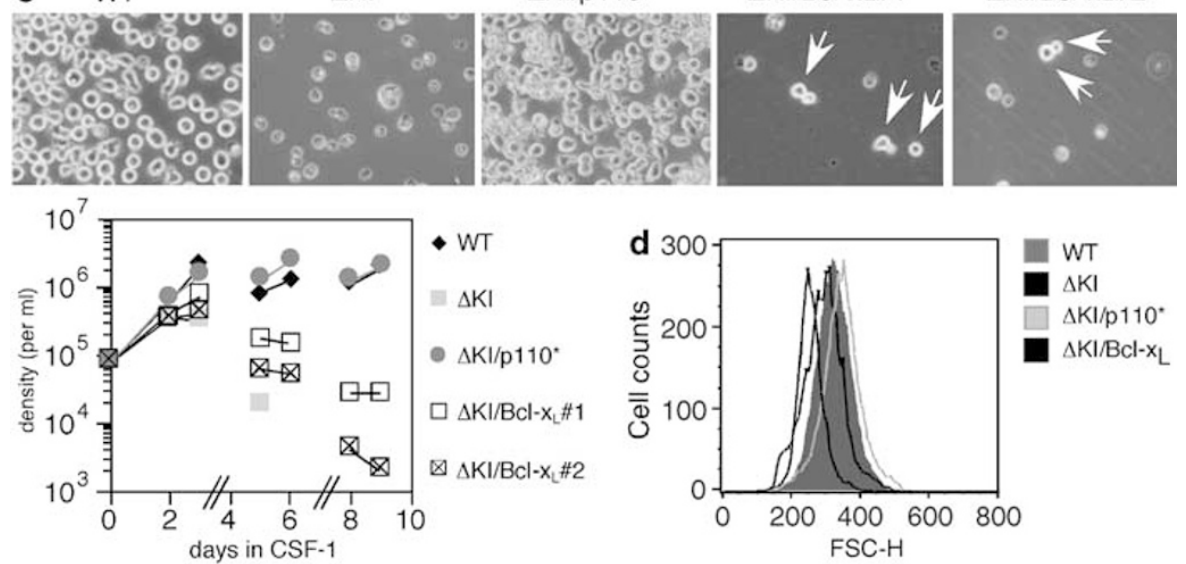

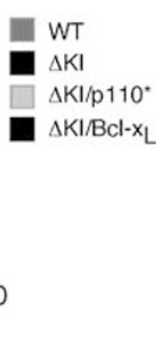

Figure 4 Neither a pancaspase inhibitor nor Bcl- $\mathrm{x}_{\mathrm{L}}$ overexpression rescues the $\Delta \mathrm{KI}$ mitogenic defect. (a) $\Delta \mathrm{KI}$ cells were preincubated with $100 \mu \mathrm{M} z-\mathrm{VAD}$-fmk (Enzyme Systems) for $2 \mathrm{~h}$ before initiation of starvation and treatment with growth factors with or without $300 \mu \mathrm{M} \mathrm{z}$-VAD-fmk. After $24 \mathrm{~h}$, aliquots were analyzed for DNA fragmentation by ELISA (left) or for MTS assay (right). Error bars refer to the means \pm S.D. of duplicates (ELISA) or triplicates (MTS). (b) $\Delta \mathrm{KI}$ clones reconstituted with the indicated proteins were analyzed for MTS activities (left) and percent viabilities (right). Cells were passaged at the times indicated by the break in the abscissa. Data for the derivatives of the $\Delta \mathrm{KI} 11$ clone are shown. This is representative of two independent experiments. Similar results were obtained for derivatives of the $\Delta \mathrm{Kl} \# 2$ clone. (c) Cells were cultured in the presence of CSF-1 and split at 1:5 ratio every 3 days into fresh media. (Top) Phase-contrast micrographs of unfixed cells were recorded on day 8 (magnification $\times 400$ ). The majority of WT cells and $\Delta \mathrm{KI}$ cells reconstituted with p110* were viable, all of the $\Delta \mathrm{KI}$ cells were dead, while viable $\Delta \mathrm{KI}$ cells that have been reconstituted with $\mathrm{Bcl}-\mathrm{X}_{\mathrm{L}}$ are indicated by arrows. (Bottom) The corresponding growth curves are shown. Data for $\Delta \mathrm{Kl}$ are not shown after day 4 since the cells were dead and values off scale. (d) Cell size was measured after $48 \mathrm{~h}$ in CSF-1 by collecting forward light scatter using a flow cytometer. The nonviable cell population was excluded by their light-scattering properties (increased side scatter and diminished forward scatter). Cells were kept continuously in culture media during the entire period of the experiment. Analysis was performed using the FlowJo v.2.7.9 software (Treestar)

of z-VAD-fmk. ${ }^{29}$ Aside from caspases, we cannot exclude that other cysteine proteases may also be inhibited.

$\mathrm{Bcl}-\mathrm{x}_{\mathrm{L}}$-overexpressing factor-dependent cell lines are used extensively to analyze cytokine deprivation-induced death. ${ }^{30}$ It has been suggested that the life-and-death problem can be considered as a balance between the levels of prosurvival and proapoptotic proteins. To further investigate whether apoptosis contributed to the death of $\Delta \mathrm{KI}$ cells, we retrovirally transduced $\Delta \mathrm{KI}$ cells with $\mathrm{Bcl}-\mathrm{x}_{\mathrm{L}}$. $\mathrm{Bcl}-\mathrm{x}_{\mathrm{L}}$ overexpression did not grossly perturb normal growth as parental $\Delta \mathrm{KI}$ and $\Delta \mathrm{KI} / \mathrm{Bcl}-\mathrm{x}_{\mathrm{L}}$ cells were similar in their abilities to proliferate in IL-3 (not shown). The viability of $\mathrm{Bcl}-\mathrm{x}_{\mathrm{L}}$ cells was high (Figure 4b, right); however, CSF-1-dependent MTS activity was not enhanced over that observed in parental or vector-control $\Delta \mathrm{KI}$ cells (Figure $4 \mathrm{~b}$, left). In support of the conclusion that $\mathrm{Bcl}-2$ or $\mathrm{Bcl}-\mathrm{x}_{\mathrm{L}}$ expression is unlikely to underlie the mitogenic defect, no difference was observed in the levels of these proteins in CSF1-treated WT or $\Delta \mathrm{KI}$ cells (Supplemental Figure S5a). Microscopic studies revealed a few cells (both viable and dead) present in long-term $\Delta \mathrm{KI} / \mathrm{Bcl}-\mathrm{x}_{\mathrm{L}}$ cultures, with the viable cells appearing smaller than those in the WT and $\Delta \mathrm{KI} / \mathrm{p} 110^{*}$ cultures (Figure 4c). To quantify this difference in cell size, forward light scatter was obtained by flow cytometry on unfixed cells after $48 \mathrm{~h}$ in culture. As shown (Figure $4 \mathrm{~d}$ ), CSF1-treated WT and $\Delta \mathrm{KI} / \mathrm{p} 110^{*}$ cells were larger (mean FSC: WT, 322; p110*, 344; $\Delta \mathrm{KI}, 291$ ) compared to Bcl- $\mathrm{X}_{\mathrm{L}}$ cells (FSC: 255). The corresponding viabilities of CSF-1-treated 
cells determined by propidium iodide exclusion were $93 \%$ (WT), 62\% $(\Delta \mathrm{KI}), 88 \%\left(\mathrm{p} 110^{*}\right)$ and $98 \%\left(\mathrm{Bcl}-\mathrm{x}_{\mathrm{L}}\right)$.

\section{CSF-1-stimulated mitogenesis is dependent on glycolysis}

In addition to cell size differences, significant MTS activity was only seen in CSF-1-treated $\Delta \mathrm{KI}$ cells expressing $\mathrm{p} 110^{*}$ or $\mathrm{E} 40 \mathrm{~K}$ but not $\mathrm{Bcl}-\mathrm{x}_{\mathrm{L}}$. Although the MTS assay is frequently used to monitor proliferation, MTS reduction depends on cellular NADH- and NADPH-dependent dehydrogenases and is an indicator of cellular redox state and metabolic function. ${ }^{31,32}$ Thus, the difference between $\Delta \mathrm{KI} / \mathrm{p} 110^{*}$ and $\Delta \mathrm{KI} /$ $\mathrm{E} 40 \mathrm{~K}$ on the one hand, and $\Delta \mathrm{KI} / \mathrm{Bcl}-\mathrm{x}_{\mathrm{L}}$ on the other, may be in the metabolic state of the cells. Importantly, overexpression of a constitutively active Akt has been reported to stimulate glycolysis ${ }^{33}$ and CSF-1 stimulates glucose uptake in macrophages. $^{34}$

We investigated the role of glucose metabolism in mediating CSF-1-dependent proliferation and survival. In fibroblasts, Akt could prevent apoptosis in the presence of the glucose analog, 2-deoxy-glucose (2-DG). ${ }^{35}$ 2-DG is phosphorylated by $\mathrm{HK}$, but is not metabolized further in the glycolytic pathway. We found that 2-DG rapidly reduced the viability of $\Delta \mathrm{KI} / \mathrm{p} 110^{*}$ cells when cultured in CSF-1 (Figure 5a), indicating that glucose metabolism, not simply glucose phosphorylation, is required. Consistently, a 100 -fold reduction in glucose prevented CSF-1 from supporting the long-term proliferation and viability of $\Delta \mathrm{KI} / \mathrm{p} 110^{*}$ cells (Figure $5 \mathrm{~b}$ ). Very similar results were obtained for WT cell (data not shown). In contrast, Bcl- $x_{L}$ overexpression inhibited the death of $\Delta \mathrm{KI} / \mathrm{Bcl}-\mathrm{x}_{\mathrm{L}}$ cells in the presence of CSF-1 and 2-DG, but did not promote proliferation (Figure 5a). This observation supports the conclusion that $\mathrm{Bcl}-\mathrm{x}_{\mathrm{L}}$ protects against cell death via a mechanism that is independent of glycolysis and that the initial CSF-1-supported proliferation of $\Delta \mathrm{KI} / \mathrm{Bcl}-\mathrm{x}_{\mathrm{L}}$ cells requires glycolysis. To test if metabolic fuels for Krebs-cycle-dependent mitochondrial ATP production could substitute for glucose, we added methyl pyruvate, a membrane-permeant ester of pyruvate, or $\alpha$ ketoisocaproic acid, which is sequentially degraded in the mitochondria to acetyl Co-A. Neither compound substituted for glucose (Figure 5b). MTS activity correlated more closely with glucose metabolism than mitochondrial events as cells cultured in $0.11 \mathrm{mM}$ glucose showed minimal MTS reduction regardless of availability of mitochondrial substrates.

Recent studies showed that 3-bromopyruvic acid (BrPA), a structural analog of pyruvate/lactate, can potently inhibit HK and deplete ATP ${ }^{36}$ at concentrations of $30-300 \mu \mathrm{M}$. We found that even $25 \mu \mathrm{M}$ of BrPA had a profound effect on proliferation and survival, with $\Delta \mathrm{KI} / \mathrm{p} 110^{*}$ and $\Delta \mathrm{KI} / \mathrm{E} 40 \mathrm{~K}$ cells exhibiting twice the sensitivity compared to WT cells (Figure 5c, left 2 panels). This observation supports a prominent role for glycolysis in mediating the rescue by $\mathrm{p} 110^{*}$ and E40K. Similar to the effect of 2-DG, $\Delta \mathrm{KI} / \mathrm{Bcl}-\mathrm{x}_{\mathrm{L}}$ cells were significantly more resistant to the death-inducing effect of BrPA (Figure $5 \mathrm{c}$, right 2 panels). We next examined lactate production. IL-3dependent cell lines derive their ATP from aerobic glycolysis with lactate as the end product. ${ }^{37}$ CSF-1-stimulated lactate production in WT cells and less so in $\Delta \mathrm{KI}$ cells (Figure $5 \mathrm{~d}$ ).
Lactate production in $\Delta \mathrm{KI}$ cells was restored upon expression of either $\mathrm{p} 110^{*}$ or $\mathrm{E} 40 \mathrm{~K}$, but not $\mathrm{Bcl}-\mathrm{x}_{\mathrm{L}}$, indicating that inhibiting cell death with $\mathrm{Bcl}-\mathrm{x}_{\mathrm{L}}$ did not prevent the metabolic arrest associated with the $\Delta \mathrm{KI}$ phenotype.

\section{The role of HK in CSF-1-mediated mitogenic signaling}

Glucose is phosphorylated by $\mathrm{HK}$, the first enzyme of glycolysis. Upregulation of HKII and other glycolytic enzymes are responsible for the highly glycolytic phenotype of malignant tumors. ${ }^{38}$ Moreover, growth factor deprivation in $\mathrm{T}$ cells downregulates HKII mRNA. ${ }^{39}$ We determined if CSF-1 regulates total cellular HK activity (Figure 6a, top). In WT cells, CSF-1 increased $\mathrm{HK}$ activity by $29 \%$, comparable to numbers reported for other growth factors (20-50\%). ${ }^{40}$ A similar enhancement was seen in $\mathrm{p} 110^{*}$ and $\mathrm{E} 40 \mathrm{~K}$, but not in $\Delta \mathrm{KI}$ cells. Basal HK activity in $\mathrm{p} 110^{*}$ and E40K cells showed a small but statistically significant increase compared to WT cells. Constitutively active Akt has been shown to maintain $\mathrm{HK}$ association with mitochondria ${ }^{13,35}$ and disruption of this interaction is sufficient to induce cytochrome $c$ release and apoptosis. ${ }^{41}$ Mitochondria (P10) were isolated from starved and CSF-1-treated 32D clones and $\mathrm{HK}$ activities determined in solubilized P10 and S10 fractions (Figure 6a, bottom). Similar to what was observed previously, ${ }^{35,41} 12-15 \%$ of total cellular HK activity was localized to the mitochondria. Overall, HK activities in the individual fractions tracked that observed in total cell lysates. $\mathrm{p} 110^{*}$ and E40K expression increased mitochondrial-associated HK activity by 33 and $19 \%$, respectively, over that seen in $\Delta \mathrm{KI}$ cells under growth factor-deprived conditions. These increases were less but of the same order of magnitude as those reported for MyrAkt. ${ }^{35}$ Whereas mitochondrial HK activity appears to be independent of IL-3 in $\mathrm{T}$ cells expressing MyrAkt, ${ }^{42}$ CSF -1 treatment had an additional and substantial effect, consistent with the finding that CSF-1 further stimulated Akt activity in $\Delta \mathrm{KI} / \mathrm{p} 110^{*}$ and $\Delta \mathrm{KI} / \mathrm{E} 40 \mathrm{~K}$ cells (Figure $3 e$ ).

As HKII is the isoform which is growth factor regulated, we determined HKII protein levels. CSF-1 induces HKII expression in a PI3-kinase-dependent manner (Figure 6b). Consistent with the HK activity data, HKII was minimally increased in $\Delta \mathrm{KI}$ and substantially restored in $\mathrm{p} 110^{*}$. We next determined if the PI3-kinase/Akt pathway has a similar effect on HKII in primary cells. We isolated bone marrow progenitors from mice and differentiated them into BMMs. Similar to what was observed in 32D cells, CSF-1-stimulated lactate production and HKII expression were shown to be partially dependent on PI3-kinase activity (Figure 6c). To examine if HKII expression is transcriptionally regulated by PI3-kinase, we utilized an HKII reporter (HK-luc). Hepatoma cell lines are known to have high glycolytic rates. ${ }^{38}$ In Hep3B cells, p110* induced an almost four-fold increase in HK luciferase activity (Figure 6d). Surprisingly, in the same experiment, E40K had minimal effects (negative results not shown). Thus, PI3-kinase could transcriptionally upregulate HKII expression.

Next, we tested the hypothesis that reduced HKII expression and activity may contribute to the $\Delta \mathrm{KI}$ phenotype. Mass populations of $\Delta \mathrm{KI}$ cells stably transfected with HKII were 

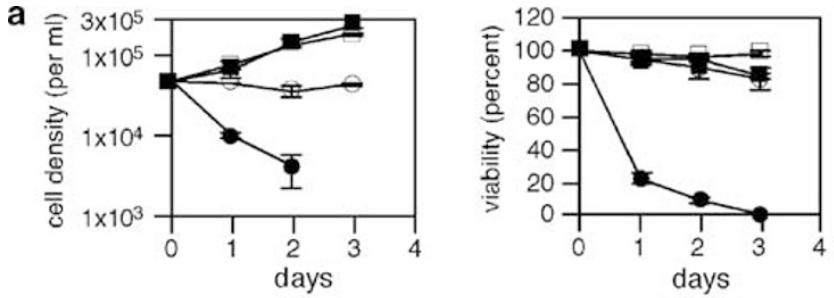

$\Delta \mathrm{KI} / \mathrm{p} 110 * 11 \mathrm{mM}$ Glc

$\Delta \mathrm{KI} / \mathrm{p} 110^{\star}, 11 \mathrm{mM} 2 \mathrm{DG}$

$\Delta \mathrm{KI} / \mathrm{Bcl}-\mathrm{x}_{\llcorner}, 11 \mathrm{mM} \mathrm{Glc}$

$\Delta \mathrm{KI} / \mathrm{Bcl}-\mathrm{x}_{L}, 11 \mathrm{mM} 2 \mathrm{DG}$
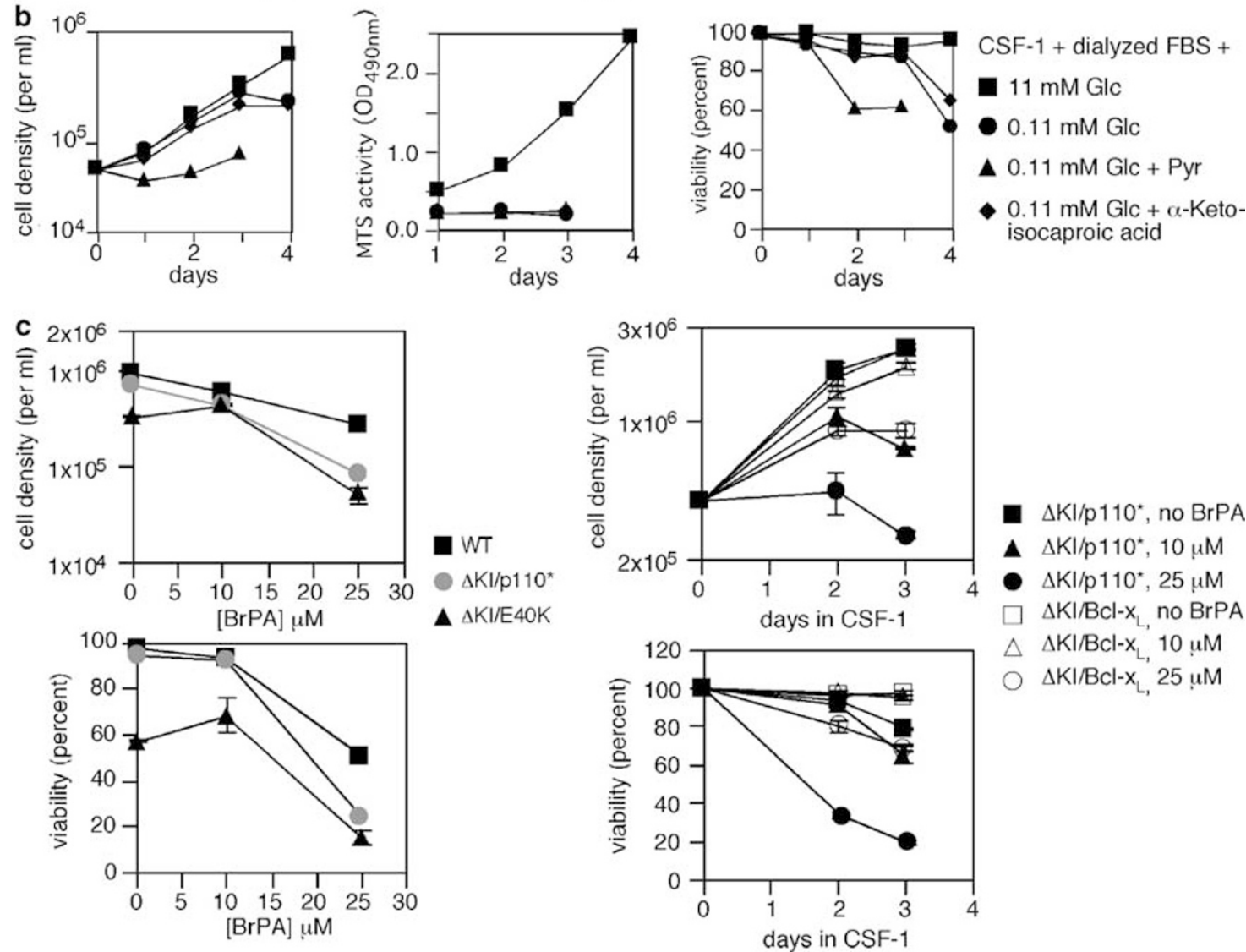

$\Delta \mathrm{KI} / \mathrm{p} 110^{*}$, no BrPA

A $\Delta \mathrm{KI} / \mathrm{p} 110^{*}, 10 \mu \mathrm{M}$

- $\Delta \mathrm{KI} / \mathrm{p} 110^{\star}, 25 \mu \mathrm{M}$

$\square \Delta \mathrm{KI} / \mathrm{Bcl}-\mathrm{x}_{\mathrm{L}}$, no BrPA

$\triangle \Delta \mathrm{KI} / \mathrm{BCl}-\mathrm{x}_{\mathrm{L},}, 10 \mu \mathrm{M}$

$\Delta \mathrm{KI} / \mathrm{BCl}-\mathrm{X}_{L}, 25 \mu \mathrm{M}$

d

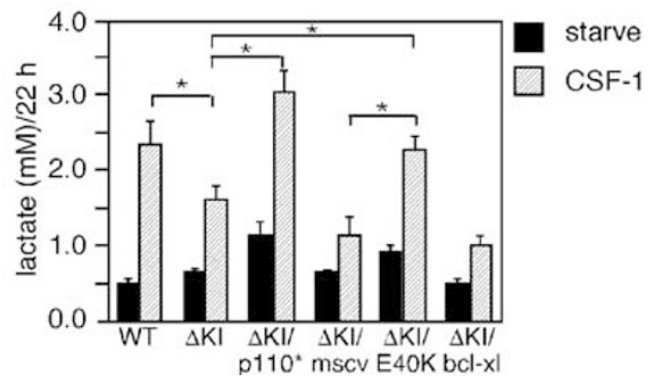

Figure 5 CSF-1-mediated proliferation and survival is glycolysis dependent. (a) Daily cell counts and viabilities were determined for $32 \mathrm{D}-\Delta \mathrm{KI} / \mathrm{p} 110^{*}$ and $\Delta \mathrm{KI} / \mathrm{Bcl}-\mathrm{x}_{\mathrm{L}}$ cells incubated in glucose-free medium with $10 \%$ dialyzed FBS and CSF-1, supplemented with $11 \mathrm{mM}$ glucose or $11 \mathrm{mM} 2-\mathrm{DG}$. Shown are the means \pm S.D. of two experiments. (b) Cells were incubated in glucose-free medium with 10\% dialyzed FBS and CSF-1. Glucose (Glc) was added to the indicated concentrations $+10 \mathrm{mM}$ methyl pyruvate (pyr) or $10 \mathrm{mM} \alpha$-ketoisocaproic acid. Cell numbers (left), MTS activities (middle) and viabilities (right) were determined daily. Shown are the results for 32D- $\Delta \mathrm{Kl} / \mathrm{p} 110^{*}$, similar results were obtained for WT cells. (c) (Left 2 panels) 32D clones were cultured in CSF-1-containing media for $24 \mathrm{~h}$ before treatment with the indicated concentrations of 3-bromo-pyruvic acid (BrPA). Cell counts and viabilities were determined $24 \mathrm{~h}$ later. Shown are the means \pm S.D. of two independent experiments. (Right 2 panels) Cells were treated similarly and monitored for $48 \mathrm{~h}$ after the addition of BrPA on day 1. Shown are the means \pm S.D. of duplicates. (d) Cumulative lactate production (means \pm S.D., $n=3$ ) in conditioned media was measured after $22 \mathrm{~h}$. All CSF-1-treated samples had equivalent numbers of viable cells at $22 \mathrm{~h}\left(3.3 \pm 0.4 \times 10^{5} / \mathrm{ml}\right) .{ }^{*} P<0.05$

tested for their ability to grow in CSF-1: after 3 days, $50 \%$ of HKII cells were viable compared to $15 \%$ of parental $\Delta \mathrm{KI}$ cells and $92 \%$ of p $110^{*}$ cells (Figure $6 \mathrm{e}$ ). MTS reduction and cell density paralleled viabilities. Without CSF-1, exogenous HKII had no effect (data not shown), indicating that CSF-1dependent signals are still essential. We had earlier observed 
a
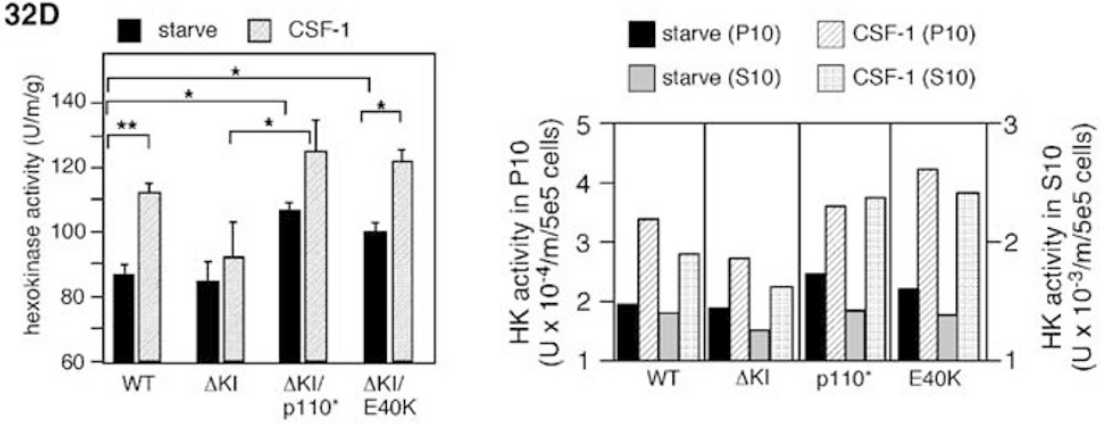

b 32D
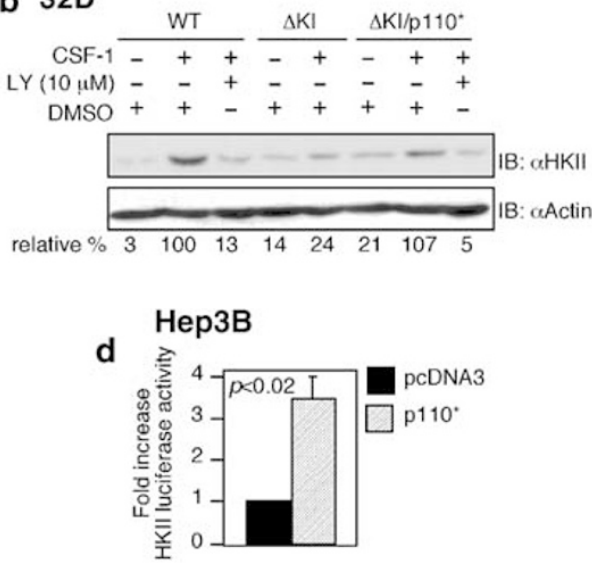

c BMM

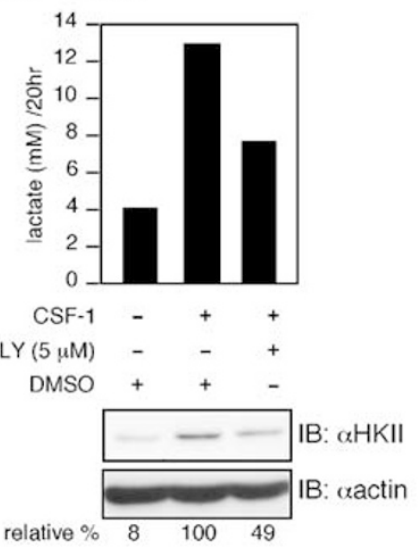

e 32D

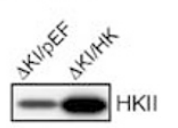

120

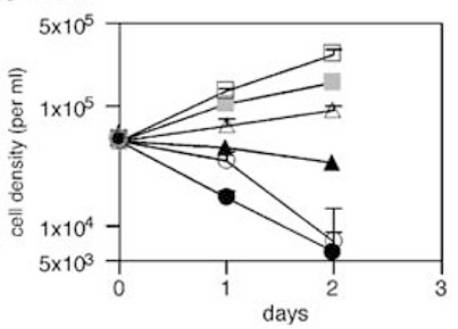

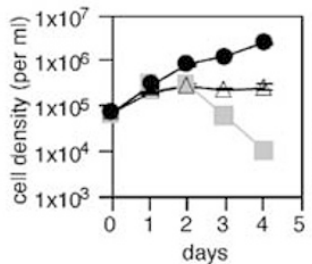
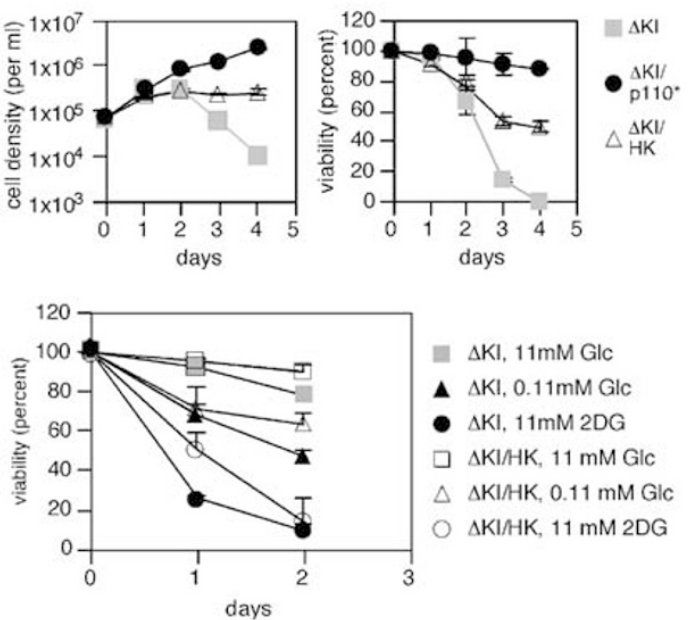

2. $\Delta \mathrm{KI}, 11 \mathrm{mM} \mathrm{Glc}$

A $\triangle \mathrm{KI}, 0.11 \mathrm{mM} \mathrm{Glc}$

- $\triangle \mathrm{KI}, 11 \mathrm{mM} 2 \mathrm{DG}$

- $\Delta \mathrm{KI} / \mathrm{HK}, 11 \mathrm{mM} \mathrm{Glc}$

$\triangle \triangle \mathrm{Kl} / \mathrm{HK}, 0.11 \mathrm{mM} \mathrm{Glc}$

- $\triangle \mathrm{KI} / \mathrm{HK}, 11 \mathrm{mM} 2 \mathrm{DG}$

Figure $6 \mathrm{PI} 3$-kinase regulates hexokinase (HK) II and HKII overexpression partially restores mitogenicity to $\Delta \mathrm{KI}$ cells. (a) (Left) $32 \mathrm{D}$ cells were starved or treated with CSF-1 for $16 \mathrm{~h}$ and total cellular HK activities determined. Shown are the means \pm S.D. $(n=3) .{ }^{*} P<0.05,{ }^{* *} P<0.005$. (Right) Cells were treated as in (a) and fractionated into mitochondria (P10) and cytosol (S10). In all, 10 and $150 \mu \mathrm{g}$, respectively, of solubilized P10 and S10 proteins were used in HK assays. To facilitate comparison between mitochondrial and cytosolic $\mathrm{HK}$ activities, the results have been normalized to $5 \times 10^{5}$ cells. Note the difference in scale between $\mathrm{HK}$ activities in S10 and P10 fractions. (b) Cells were starved for $6 \mathrm{~h}$, treated with $10 \mu \mathrm{M}$ LY294002 or DMSO for $1 \mathrm{~h}$ before CSF-1 addition. Lysates were prepared $16 \mathrm{~h}$ later and immunoblotted with the indicated antibodies. Relative percent refers to relative HKII intensities, normalized to actin levels. (c) BMMs were deprived of CSF-1 or treated with CSF-1 in the presence of DMSO or LY294002. After $20 \mathrm{~h}$, culture medium was collected for lactate determination, cells were lysed and the same amount of protein for each condition was immunoblotted as shown. Relative percent calculated as in (a). (d) Luciferase activity was measured in Hep3B cells cotransfected with HKII-luc and vector or p110*. Shown are the means \pm S.D. $(n=4)$. (e) (Left) Shown is an HKII immunoblot of total cell lysates prepared from $\Delta \mathrm{KI}$ cells stably transfected with vector or HKII. (Middle) Day 3 MTS activities determined in the presence of CSF-1. Plotted are the means \pm S.D. $(n=4)$. (Right two panels) Shown are the cell density and viability over 4 days from a representative experiment out of two. (f) Experiment was performed as described in Figure $5 a$ and b. Shown are the means \pm S.D. of duplicates

that when 2-DG was substituted for glucose, CSF-1 was unable to support the proliferation and survival of WT and $\Delta \mathrm{KI} /$ p110* cells (Figure 5a and data not shown). Here, we examined if overexpression of HKII could bypass the glycolytic block. Figure $6 f$ shows that HKII overexpression delayed cell death in the presence of 2-DG but both $\Delta \mathrm{KI}$ and $\Delta \mathrm{KI} / \mathrm{HK}$ cells were dead by $48 \mathrm{~h}$. Thus, CSF-1-dependent proliferation of $\Delta \mathrm{KI} / \mathrm{HK}$ is dependent on glycolysis. However, 
in media containing reduced $(0.11 \mathrm{mM})$ glucose, the difference in proliferation between $\Delta \mathrm{KI}$ and $\Delta \mathrm{KI} / \mathrm{HK}$ cells was more pronounced compared to normal $(11 \mathrm{mM})$ glucose, consistent with $\Delta \mathrm{KI} / \mathrm{HK}$ cells being better able to support glycolysis.

\section{Discussion}

Rapidly proliferating cells such as myeloid progenitors and functionally active, nondividing cells such as BMMs and neutrophils exhibit high metabolic rates and undergo aerobic glycolysis. ${ }^{43}$ Recent studies point to a prominent connection between growth factor signaling and metabolic control. CSF1 's physiological role is to maintain the monocyte/macrophage compartment. CSF-1R activation initiates a complex signaling program, culminating in proliferation, growth, survival and, in some cases, differentiation. Although it has been suggested that PI3-kinase is involved in mediating CSF-1 survival, how PI3-kinase accomplishes this function is unknown; nor is it known if other pathways such as the Stats contribute, and if these pathways are linked to metabolism. In response to CSF-1, the $\Delta \mathrm{KI}$ receptor showed absent Stat3 phosphorylation and reduced but still significant PI3-kinase activity; activation of Erk, JNK, Rac, Stat5, p70 ${ }^{\text {S6K }}$ and 4EBP1 is intact. CSF-1 engaged $\Delta \mathrm{KI}$ to initiate DNA synthesis; this did not result in long-term proliferation and the defect was not rescued by blocking apoptosis. Whereas Stat3 did not appear to play a critical role in CSF-1-stimulated mitogenesis, PI3-kinase and, to a lesser extent, Erk were essential for a maximal response. Importantly, robust PI3-kinase signaling was required for CSF-1-dependent mitogenesis, one effect of which was to maintain adequate glycolysis via the induction and activation of glycolytic enzymes, such as HKII. We also demonstrate that the PI3-kinase/Akt pathway can regulate $\mathrm{HKII}$ transcriptionally. Our studies of the $\Delta \mathrm{KI}$ mutant provide a clear example of the importance of maintaining metabolic homeostasis, revealed in settings where apoptosis is significantly suppressed by growth factor signals, as in the case of $\Delta \mathrm{KI}$, or where apoptosis is essentially eliminated as when $\mathrm{BCl}-\mathrm{x}_{\mathrm{L}}$ is overexpressed.

Although the $\Delta \mathrm{KI}$ receptor failed to provide sufficient PI3kinase signaling for a full, CSF-1 mitogenic response, the reduced level of PI3-kinase activation was still important as PI3-kinase inhibitors significantly prevented the proliferation and survival of $\Delta \mathrm{KI}$ cells. The possibility that a threshold level of PI3-kinase signaling is necessary for mitogenesis implies that different PI3-kinase-dependent pathways may require different PI3-kinase signal intensities for activation. This hypothesis is consistent with the observation that $\mathrm{PIP}_{3}$ binds to its substrates - proteins with pleckstrin homology domains - with varying affinities and specificities. ${ }^{44}$ Our findings with p110* demonstrated that PI3-kinase activation alone does not substitute for growth factor action. Similarly, in fibroblasts, activation of myristoylated p110 (Myrp110) is sufficient to induce short-term DNA synthesis only, as cells succumb to apoptosis in the absence of serum. ${ }^{26}$ In T cells, Myrp110 cannot stimulate proliferation unless in combination with other signals such as Stat5. ${ }^{45}$ Our results showed that CSF-1dependent mitogenesis required the collaboration of both the Erk and PI3-kinase pathways. Although Akt is a major
PI3-kinase target, it is possible that Akt activation is not equivalent to the activation of PI3-kinase. A previous study had shown that E40K and MyrAkt exerted very similar effects on pro-B-cell survival. ${ }^{46}$ In contrast, we found that E40K, despite being expressed at high levels, was not as effective as p110* in correcting the CSF-1 mitogenic defect present in $32 \mathrm{D}-\Delta \mathrm{KI}$ cells. As GSK3 and FKHRL1 are phosphorylated equivalently downstream of cells expressing either $\mathrm{p} 110^{*}$ or $\mathrm{E} 40 \mathrm{~K}$, there is a potential role for Akt-independent mechanisms. PI3-kinase-dependent but Akt-independent pathways have been implicated in various scenarios: for example, in mammary tumorigenesis, Myrp110 but not MyrAkt promotes proliferation in low serum. ${ }^{47}$

There is strong evidence in the literature linking the PI3kinase pathway to p70s6K and 4E-BP1 via TSC1/2 and mTOR, and their phosphorylation is markedly increased in PTEN-deficient cells. Yet, CSF-1-provoked phosphorylation of these two proteins as assayed by gel mobility shifts was not noticeably affected in $\Delta \mathrm{KI}$ cells (Supplemental Figure S2), implying that maximal activation of mTOR does not require maximal activation of PI3-kinase. However, both p760s6K and 4E-BP1 are phosphorylated at multiple sites and we cannot completely exclude the possibility that individual sites may be differentially phosphorylated in WT or $\Delta \mathrm{KI}$ cells. Nevertheless, the absence of a significant reduction in p70s6K and 4E-BP1 phosphorylation in response to CSF-1 in $\Delta \mathrm{KI}$ cells compared to WT cells suggests that abnormal mTOR-regulated protein translation is not the cause of the $\Delta \mathrm{KI}$ mitogenic defect.

The $50 \%$ reduction in CSF-1-provoked DNA synthesis observed in $\Delta \mathrm{KI}$ cells compared to WT cells was not owing to failure in $G_{1}$ cyclin or c-myc induction or in the repression of p21 ${ }^{\mathrm{Cip} 1}$ and p27 Kip1 levels (Supplemental Figure S5). Given that cell cycle progression and cell growth are coordinated events, we suggest that defective glycolysis and hence cell growth may contribute to the block in S-phase entry. Glucosedependent control of $G_{1} / S$ entry has been proposed. ${ }^{48}$ Glycolysis generates ATP and in rapidly proliferating myeloid cells, glycolysis rather than oxidative phosphorylation is the main source of ATP. ${ }^{37}$ Glycolysis also provides intermediates for the biosynthesis of purines, pyrimidines, some amino acids and phospholipids. As well, glucose-6-phosphate produced by HK serves as the substrate for the pentose phosphate pathway that produces $\mathrm{NADPH}$, the main regulator of the cell's redox potential.

In 32D cells, glucose metabolism plays a key role in supporting CSF-1-mediated proliferation/survival since glucose deprivation or inhibition of glycolysis markedly reduced cell proliferation and viability, not corrected by the inclusion of pure mitochondrial fuels. Five lines of evidence support a metabolic contribution to the rescue of the $\Delta \mathrm{KI}$ death phenotype by $\mathrm{p} 110^{*}$ or E40K. First, MTS reduction, which is a measure of cellular dehydrogenase activity rather than viability per se, correlated with CSF-1-dependent growth and proliferation. This conclusion is based on the observation that although cells expressing either $\mathrm{p} 110^{*}$ or $\mathrm{Bcl}-\mathrm{x}_{\mathrm{L}}$ demonstrated high viabilities in the presence of CSF-1, only those expressing $\mathrm{p} 110^{*}$ showed high MTS activity and restored proliferation (Figure $4 b$ ). Second, compared to WT cells, $\Delta \mathrm{KI}$ cells expressing $\mathrm{p} 110^{*}$ or $\mathrm{E} 40 \mathrm{~K}$ were more sensitive to BrPA, a 
glycolytic inhibitor (Figure $5 \mathrm{c}$ ). Third, lactate production, a direct measure of glycolytic function in 32D cells, also paralleled cell growth and proliferation (Figure 5d). Fourth, glucose reduction has a more noticeable effect on the proliferation and survival of $\Delta \mathrm{KI}$ cells (Figure 6f) compared to $\Delta \mathrm{KI} / \mathrm{p} 110^{*}$ cells (Figure $5 \mathrm{~b}$ ), consistent with $\Delta \mathrm{KI} / \mathrm{p} 110^{*}$ cells having more of a glycolytic reserve than $\Delta \mathrm{KI}$ cells. Lastly, CSF-1-induced HK activity was diminished in $\Delta \mathrm{KI}$ cells compared to WT cells and restored by $\mathrm{p} 110^{*}$ (Figure 6a). Previous studies showed that enforced overexpression of MyrAkt in B cells was completely protective against cell death induced by IL-3 withdrawl and that this was dependent on glucose availability. ${ }^{42}$ When a signaling pathway is dysregulated, such as from chronic Akt activation owing to MyrAkt overexpression, cells can become addicted to the growth/ survival effects conferred by the pathway and exhibit hypersensitivity to inhibition of that pathway. Our results extend the observations made with MyrAkt to more physiologic situations such as the $\Delta \mathrm{KI}$ receptor where growth factor signaling and feedback mechanisms remain largely intact. We demonstrate that a modest reduction in the activity of the PI3kinase/Akt pathway can have an impact on the glycolytic pathway and this can be reversed by an equally modest increase in PI3-kinase/Akt activity, although the effects on proliferation/survival appeared to be quite profound.

Our findings are reminiscent of earlier reports showing that growth factor deprivation in T cells can lead to a decrease in cell size owing to diminished nutrient utilization, not corrected by $\mathrm{BCl}-\mathrm{x}_{\mathrm{L}}$ expression. ${ }^{30}$ Thus, our data are consistent with a metabolic defect in $\Delta \mathrm{KI}$ cells, accentuated by Bcl- $x_{\mathrm{L}}$ expression. In the case of T-cell neglect, removal of growth factor presumably inactivates most promitogenic signaling pathways. In contrast, several important signaling pathways were still active in $\Delta \mathrm{KI}$ cells cultured in CSF-1 (Figure 2 and Supplemental Figures S2 and S3), but apparently their collaboration with $\mathrm{Bcl}-\mathrm{x}_{\mathrm{L}}$ was not sufficient to rescue mitogenesis. The death-suppressing effect of Bcl- $x_{L}$ occurred in a glycolysis-independent manner as the majority of $\Delta \mathrm{KI} / \mathrm{Bcl}$ $x_{L}$ cells remained viable in the presence of 2-DG or BrPA. However, 2-DG and BrPA prevented CSF-1-mediated proliferation of these cells, supporting our conclusion that defective metabolism underlies the reduced ability of the $\Delta \mathrm{KI}$ receptor to support long-term proliferation. Previously, $\mathrm{Bcl}-\mathrm{x}_{\mathrm{L}}$ was found to protect against IL-3-withdrawal-induced cell death under reduced glucose conditions. ${ }^{30}$ We now extend these findings to show that $\mathrm{Bcl}-\mathrm{x}_{\mathrm{L}}$ is protective even when glycolysis is blocked by 2-DG. It is possible that 2-DG-6phosphate produced by HK-mediated phosphorylation of 2DG can enter the pentose phosphate shunt and allow NADPH recycling, ${ }^{49}$ thereby maintaining a reduced cellular state and contributing towards cell survival.

In this study, we also provide evidence showing that the PI3-kinase pathway regulates HKII. In myeloid progenitors and BMMs, CSF-1 maintained HKII protein levels in a PI3kinase-dependent manner, and in hepatoma cells, p110* transactivated an HKII promoter reporter. Notably, E40K was unable to do so, suggesting that the effect of PI3-kinase is mediated via an Akt-independent pathway. Pedersen et al. ${ }^{50}$ showed that members of the Sp and CREB families bind to the HKII promoter in hepatoma cells and, in insulin-responsive tissues, SREBP-1 also appears to be a regulator. ${ }^{51}$ Whether these transcriptional factors provide a link to PI3-kinase remains to be determined.

HK overexpression protects against cell death induced by growth factor withdrawal/UV ${ }^{35}$ or oxidants. ${ }^{40}$ In agreement, HKII overexpression in $\Delta \mathrm{KI}$ cells, in collaboration with CSF-1, increased MTS activity and cell viability. Compared to p110*, HKII overexpression was only partially effective. One possible explanation is that aside from HKII, PI3-kinase regulates glucose uptake and other enzymes of the glycolytic pathway. For example, PFK2/fructose 2,6-bisphosphatase is both transcriptionally regulated by PI3-kinase and phosphorylated by Akt. $^{52}$ In addition, PI3-kinase is implicated in insulinmediated activation of pyruvate kinase. ${ }^{53}$ Thus, it appears that PI3-kinase can target glycolysis at multiple points to increase flux.

In summary, our study demonstrates that, in the context of growth factor action, depending on the strength of the induced signal, PI3-kinase can have important, differential effects on downstream pathways. This conclusion may have bearing when considering the phenotypes of tumors with constitutive PI3-kinase activation. For example, PTEN is altered at high frequencies in human cancers, resulting in varying degrees of inactivation. Based on our findings, we hypothesize that depending on the degree of PTEN inactivation, different tumors can exhibit differences in cell survival and glycolytic rates. Loss of PTEN also enhances expression of hypoxiainducible factor- $1 \alpha$, which induces many genes, including glycolytic enzymes, providing another link between PI3kinase and glycolysis. Thus, consistent with previous suggestions, PI3-kinase activity may contribute to the 'Warburg effect' (aerobic glycolysis) of human cancers. ${ }^{12}$

\section{Materials and Methods}

\section{Materials and cell culture}

Unless stated otherwise, all chemicals were from Sigma-Aldrich and cell culture reagents from Invitrogen. The 32D clones expressing WT or $\Delta \mathrm{KI}$ -

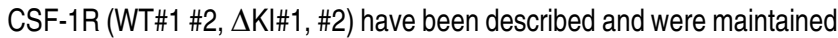
in RPMI 1640 with $10 \%$ FBS and 5\% WEHI-conditioned medium. ${ }^{10}$ They will be referred to as WT or $\Delta \mathrm{KI}$ clones. CSF-1 (Genetics Institute) was used at $10 \mathrm{nM}$ and IL-3 (BD Biosciences or PeproTech) at $10 \mathrm{ng} / \mathrm{ml}$. Glucose-free medium containing $2 \mathrm{mM}$ L-glutamine and dialyzed FBS (Hyclone) was used for glucose-deprivation experiments, with the desired concentrations of glucose or other metabolic fuels. BrPA was prepared fresh as a $25 \mathrm{mM}$ stock solution in PBS and titrated to $\mathrm{pH} 7$ before use.

\section{Murine BMM isolation and culture}

Bone marrow progenitors flushed from the femurs and tibias of 3- to 5-week-old C3H/HeN mice (Harlan) were plated in $\alpha \mathrm{MEM}$ with $15 \% \mathrm{FBS}$, $2 \mathrm{mM}$ glutamine, $12 \mathrm{ng} / \mathrm{ml} \mathrm{rhCSF}-1$ and $15 \mathrm{ng} / \mathrm{ml} \mathrm{rmlL}-3$. After $24 \mathrm{~h}$, nonadherent cells were collected and layered on a Ficoll-Hypaque gradient. Cells from the interface were plated in the same medium containing $120 \mathrm{ng} / \mathrm{ml}$ rCSF-1 but no IL-3. Fresh CSF-1 was added every second day and the medium replaced on the day before starvation. Day 7 macrophages were used for all experiments. 


\section{Plasmids, transfections and retroviral transductions}

Stable $\Delta \mathrm{KI}$ cell lines expressing $\mathrm{p} 110^{*}$ were established by electroporation with pCG-p110* and hygromycin selection. Stable $\Delta \mathrm{Kl}$ cell lines expressing HKII or constitutively active Stat $3 \mathrm{C}^{24}$ were derived by electroporation with pEFIRES-p ${ }^{54}$ plasmids and mass populations selected in $1 \mu \mathrm{g} / \mathrm{ml}$ of puromycin. Transient transfections were performed using Lipofectamine 2000 (Invitrogen). WT-Akt, K179M-Akt and E40K-Akt constructs were in pCMV6. For retroviral transductions, CDNAs encoding Akt or BCl- $x_{L}$ in pMSCV-IRES-GFP were transiently transfected into BOSC23 cells. Supernatants were used to infect two clones of $\triangle \mathrm{KI}$. GFPpositive cells were sorted by FACS (BD Vantage SE) $72 \mathrm{~h}$ after infection. The luciferase reporter was driven by the $4.3 \mathrm{~kb}$ rat HKII promoter (HKluc). Hep3B cells were transiently transfected with $0.5 \mu \mathrm{g}$ each of HK-luc and either pcDNA or $\mathrm{p} 110^{*}$ together with $5 \mathrm{ng}$ of pRL-TK. Cells were placed in glucose-free medium supplemented with $0.1 \%$ FBS, $1 \mathrm{mM}$ sodium pyruvate and $5 \mathrm{mM}$ glucose for $24 \mathrm{~h}$ before assaying for luciferase reporter activity using the Dual Luciferase Assay kit (Promega).

\section{Proliferation assays}

Cell culture experiments were performed in triplicate. Cells were washed three times in RPMI/2\% FBS before seeding into RPMI/10\% FBS alone, or with CSF-1 or IL-3. Proliferation was determined by cell counting using a hemocytometer and the MTS tetrazolium assay (Promega CellTiter $96^{\mathrm{TM}}$ ). Viability was assessed by Trypan Blue exclusion. In inhibitor studies, cells were pretreated with PD98059 (Cell Signaling), wortmannin (Sigma) or LY294002 (BioMol) for $1 \mathrm{~h}$ and the volume of diluent (DMSO) equalized in all samples. In growth studies, wortmannin was added every 2 day owing to its instability. For cell cycle analysis, cells were fixed in ethanol and incubated with $50 \mu \mathrm{g} / \mathrm{ml}$ propidium iodide and $50 \mu \mathrm{g} / \mathrm{ml}$ RNAse A followed by analysis on a FACScalibur flow cytometer (BD Biosciences). BrdU uptake was measured by FACS (FITC BrdU Flow kit, BD Biosciences).

\section{Apoptosis assays}

DNA fragmentation was detected by an ELISA assay that quantifies cytosolic histone-associated DNA fragments (Roche Diagnostics). Annexin-V-FITC-stained cells were analyzed by FACS (BD Biosciences).

\section{Protein analysis}

Cells were deprived of serum and growth factors before stimulation and lysis in LB (20 mM Tris, pH 7.4, 2 mM EDTA, $100 \mathrm{mM} \mathrm{NaCl}, 50 \mathrm{mM} \mathrm{NaF}$, $50 \mathrm{mM} \beta$-glycerophosphate, $1 \%$ NP40, 10\% glycerol, $1 \mathrm{mM}$ dithiothreitol) with $1 \mathrm{mM} \mathrm{Na}_{3} \mathrm{VO}_{4}$ and protease inhibitors. Western blotting was performed as described previously. ${ }^{10}$ Blots were developed by ECL (Amersham). Multiple exposures for each blot were obtained and quantified in the linear range by densitometry. ${ }^{10}$ Antibodies against $\beta$ actin, Akt1, HKII, p110 $\alpha$ and Stat3 were from Santa Cruz Biotechnology. Phospho-specific antibodies were from Cell Signaling Technology.

\section{Mitochondria preparation}

Cells were cultured for $16 \mathrm{~h}$ in the absence or presence of CSF-1. Typically, between $4 \times 10^{7}$ and $1 \times 10^{8}$ cells were used for each condition. Cells were washed twice in PBS, resuspended in MIB $(200 \mathrm{mM}$ mannitol, $70 \mathrm{mM}$ sucrose, $1 \mathrm{mM}$ EGTA, $10 \mathrm{mM}$ HEPES, pH 7.4 supplemented with protease inhibitors) at $8 \times 10^{7}$ cells $/ \mathrm{ml}$ and incubated on ice for $15 \mathrm{~min}$. Cells were homogenized by 50 up-and-down strokes of a $2 \mathrm{ml}$ Dounce homogenizer (Wheaton) followed by 20 passages through a $26 \mathrm{G}$ needle. Nuclei and unbroken cells were removed by centrifugation at $800 \times g$ for $10 \mathrm{~min}$. The supernatant was centrifuged at the same settings to remove residual debris and the cleared supernatant was then centrifuged at $10000 \times g$ for $20 \mathrm{~min}$. The pellet (P10) was used as the heavy membrane fraction and solubilized in lysis buffer. The supernatant (S10) was similarly solubilized. All operations were performed at $4^{\circ}$.

\section{L-Lactate measurements}

Lactate in the culture medium was measured as described ${ }^{37}$ using a kit (Sigma, 826-UV).

\section{HK activity}

HK activity in $150 \mu \mathrm{g}$ of cell lysates or $10 \mu \mathrm{g}$ of solubilized P10 containing mitochondria was performed using a standard glucose-6-phosphate dehydrogenase (G6PD) coupled assay as described. ${ }^{40}$ One unit is the amount of activity that results in the coupled formation of $1 \mu \mathrm{mol}$ of $\mathrm{NADPH} / \mathrm{min}$ at $25^{\circ} \mathrm{C}$ in the presence of glucose, G6PD, $\beta$-NADP and ATP.

\section{Statistical analysis}

$P$-values were obtained using the Student's two-sided $t$-test.

\section{Acknowledgements}

We thank the Genetics Institute for CSF-1 and Drs. Peter Blume-Jensen, Jackie Bromberg, Sami Heikkinen, Steve Hobbs, Eugene Johnson, Anke Klipple, Arthur Nienhuis and Peter Pedersen for reagents. Drs. Channing Der, Brooks Robey and Richard Stanley provided helpful discussions. This work was supported by National Institutes of Health Grant R01-CA85368 (to AW-ML). Electron microscopy was performed at the Microscopy and Image Analysis Lab, at the University of Michigan, with support from the Michigan Diabetes Research and Training Center (P60-DK20572) and the University of Michigan Comprehensive Cancer Center (NIH P30 CA46592).

\section{References}

1. Chitu V and Stanley ER (2006) Colony-stimulating factor-1 in immunity and inflammation. Curr. Opin. Immunol. 18: 39-48.

2. Hubel K, Dale DC and Liles WC (2002) Therapeutic use of cytokines to modulate phagocyte function for the treatment of infectious diseases: current status of granulocyte colony-stimulating factor, granulocyte-macrophage colony-stimulating factor, macrophage colony-stimulating factor, and interferon-gamma. J. Infect. Dis. 185: 1490-1501.

3. Conway JG, McDonald B, Parham J, Keith B, Rusnak DW, Shaw E, Jansen M, Lin P, Payne A, Crosby RM, Johnson JH, Frick L, Lin MH, Depee S, Tadepalli S, Votta B, James I, Fuller K, Chambers TJ, Kull FC, Chamberlain SD and Hutchins JT (2005) Inhibition of colony-stimulating-factor-1 signaling in vivo with the orally bioavailable cFMS kinase inhibitor GW2580. Proc. Natl. Acad. Sci. USA 102: 16078-16083.

4. Lee AW-M (1999) Synergistic activation of mitogen-activated protein kinase by cyclic AMP and myeloid growth factors opposes cyclic AMP's growth-inhibitory effects. Blood 93: 537-553. 
5. Shurtleff S, Downing J, Rock C, Hawkins S, Roussel M and Sherr C (1990) Structural features of the colony-stimulating factor 1 receptor that affect its association with phosphatidylinositol 3-kinase. EMBO J. 9: 2415-2421.

6. Hamilton JA (1997) CSF-1 signal transduction. J. Leukocyte Biol. 62: 145-155.

7. Alonso G, Koegl M, Mazurenko N and Courtneidge S (1995) Sequence requirements for binding of Src family tyrosine kinases to activated growth factor receptors. J. Biol. Chem. 270: 9840-9848.

8. Rohde CM, Schrum J and Lee AW-M (2004) A juxtamembrane tyrosine in the colony stimulating factor-1 receptor regulates ligand-induced Src association, receptor kinase function, and down-regulation. J. Biol. Chem. 279: 43448-43461.

9. Pixley FJ and Stanley ER (2004) CSF-1 regulation of the wandering macrophage: complexity in action. Trends Cell Biol. 14: 628-638.

10. Lee AW-M and States DJ (2000) Both Src-dependent and -independent mechanisms mediate phosphatidylinositol 3-kinase regulation of colony stimulating factor 1-activated mitogen-activated protein kinases in myeloid progenitors. Mol. Cell. Biol. 20: 6779-6798.

11. Bader AG, Kang S, Zhao L and Vogt PK (2005) Oncogenic PI3K deregulates transcription and translation. Nat. Rev. Cancer 5: 921-929.

12. Frauwirth KA and Thompson CB (2004) Regulation of $T$ lymphocyte metabolism. J. Immunol. 172: 4661-4665.

13. Majewski N, Nogueira V, Bhaskar P, Coy PE, Skeen JE, Gottlob K, Chandel NS, Thompson CB, Robey RB and Hay N (2004) Hexokinase-mitochondria interaction mediated by akt is required to inhibit apoptosis in the presence or absence of bax and bak. Mol. Cell 16: 819-830.

14. Manning BD and Cantley LC (2003) United at last: the tuberous sclerosis complex gene products connect the phosphoinositide 3-kinase/Akt pathway to mammalian target of rapamycin (mTOR) signalling. Biochem. Soc. Trans. 31: 573-578.

15. Kelley TW, Graham MM, Doseff Al, Pomerantz RW, Lau SM, Ostrowski MC, Franke TF and Marsh CB (1999) Macrophage colony-stimulating factor promotes cell survival through Akt/protein kinase B. J. Biol. Chem. 274 26393-26398.

16. Munugalavadla V, Borneo J, Ingram DA and Kapur R (2005) p85\{alpha\} subunit of class IA PI-3 kinase is crucial for macrophage growth and migration. Blood 106: 103-109.

17. Leverrier $Y$, Okkenhaug K, Sawyer C, Bilancio A, Vanhaesebroeck B and Ridley AJ (2003) Class I phosphoinositide 3-kinase p110beta is required for apoptotic cell and Fcgamma receptor-mediated phagocytosis by macrophages. J. Biol. Chem. 278: 38437-38442.

18. Ueki K, Fruman DA, Yballe CM, Fasshauer M, Klein J, Asano T, Cantley LC and Kahn CR (2003) Positive and negative roles of p85 alpha and p85 beta regulatory subunits of phosphoinositide 3-kinase in insulin signaling. J. Biol. Chem. 278: 48453-48466.

19. Sugatani T and Hruska KA (2005) Akt1/Akt2 and mammalian target of rapamycin/Bim play critical roles in osteoclast differentiation and survival, respectively, whereas Akt is dispensable for cell survival in isolated osteoclast precursors. J. Biol. Chem. 280: 3583-3589.

20. Choudhury GG, Wang LM, Pierce J, Harvey SA and Sakaguchi AY (1991) A mutational analysis of phosphatidylinositol-3-kinase activation by human colony-stimulating factor-1 receptor. J. Biol. Chem. 266: 8068-8072.

21. Lee AW-M and Nienhuis A (1990) Mechanism of kinase activation in the receptor for colony-stimulating factor 1 . Proc. Natl. Acad. Sci. USA 87: 7270-7274.

22. Green DR and Kroemer G (2004) The pathophysiology of mitochondrial cell death. Science 305: 626-629.

23. Darnell Jr JE (2002) Transcription factors as targets for cancer therapy. Nat. Rev. Cancer 2: 740-749.

24. Bromberg JF, Wrzeszczynska MH, Devgan G, Zhao Y, Pestell RG, Albanese C and Darnell Jr JE (1999) Stat3 as an oncogene. Cell 98: 295-303.

25. McLemore ML, Grewal S, Liu F, Archambault A, Poursine-Laurent J, Haug J and Link DC (2001) STAT-3 activation is required for normal G-CSF-dependent proliferation and granulocytic differentiation. Immunity 14: 193-204.

26. Klippel A, Escobedo M, Wachowicz M, Apell G, Brown T, Giedlin M, Kavanaugh W and Williams LT (1998) Activation of phosphatidylinositol 3-kinase is sufficient for cell cycle entry and promotes cellular changes characteristic of oncogenic transformation. Mol. Cell. Biol. 18: 5699-5711.

27. Yu J, Zhang Y, Mcllroy J, Rordorf-Nikolic T, Orr G and Backer J (1998) Regulation of the p85/p110 phosphatidylinositol 3-kinase: stabilization and inhibition of the $p 110 \alpha$ catalytic subunit by the $p 85$ regulatory subunit. Mol. Cell. Biol. 18: 1379-1387.

28. Bellacosa A, Chan T, Ahmed N, Datta K, Malstrom S, Stokoe D, McCormick F, Feng J and Tsichlis P (1998) Akt activation by growth factors is a multiple-step process: the role of the PH domain. Oncogene 17: 313-325.

29. Clark SW, Fee BE and Cleveland JL (2002) Misexpression of the eyes absent family triggers the apoptotic program. J. Biol. Chem. 277: 3560-3567.

30. Rathmell J, Heiden MV, Harris M, Frauwirth K and Thompson CB (2000) In the absence of extrinsic signals, nutrient utilization by lymphocytes is insufficient to maintain either cell size or viability. Mol. Cell 6: 683-692.

31. Marshall NJ, Goodwin CJ and Holt SJ (1995) A critical assessment of the use of microculture tetrazolium assays to measure cell growth and function. Growth Regul. 5: 69-84.

32. Segu VB, Li G and Metz SA (1998) Use of a soluble tetrazolium compound to assay metabolic activation of intact beta cells. Metabolism 47: 824-830.

33. Plas DR, Talapatra S, Edinger AL, Rathmell JC and Thompson CB (2001) Akt and $\mathrm{BCl}-\mathrm{xL}$ promote growth factor-independent survival through distinct effects on mitochondrial physiology. J. Biol. Chem. 276: 12041-12048.

34. Hamilton J, Vairo G and Lingelbach S (1988) Activation and proliferation signals in murine macrophages: stimulation of glucose uptake by hemopoietic growth factors and other agents. J. Cell. Physiol. 134: 405-412.

35. Gottlob K, Majewski N, Kennedy S, Kandel E, Robey RB and Hay N (2001) Inhibition of early apoptotic events by Akt/PKB is dependent on the first committed step of glycolysis and mitochondrial hexokinase. Genes Dev. 15: 1406-1418.

36. Ko YH, Smith BL, Wang Y, Pomper MG, Rini DA, Torbenson MS, Hullihen J and Pedersen PL (2004) Advanced cancers: eradication in all cases using 3-bromopyruvate therapy to deplete ATP. Biochem. Biophys. Res. Commun. 324: 269-275.

37. Garland J and Halestrap A (1997) Energy metabolism during apoptosis. J. Biol. Chem. 272: 4680-4688.

38. Pedersen PL, Mathupala S, Rempel A, Geschwind JF and Ko YH (2002) Mitochondrial bound type II hexokinase: a key player in the growth and survival of many cancers and an ideal prospect for thetherapeutic intervention. Biochim. Biophys. Acta 1555: 14-20.

39. Vander Heiden MG, Plas DR, Rathmell JC, Fox CJ, Harris MH and Thompson CB (2001) Growth factors can influence cell growth and survival through effects on glucose metabolism. Mol. Cell. Biol. 21: 5899-5912.

40. Bryson JM, Coy PE, Gottlob K, Hay N and Robey RB (2002) Increased hexokinase activity, of either ectopic or endogenous origin, protects renal epithelial cells against acute oxidant-induced cell death. J. Biol. Chem. 277: $11392-11400$.

41. Majewski N, Nogueira V, Robey RB and Hay N (2004) Akt inhibits apoptosis downstream of BID cleavage via a glucose-dependent mechanism involving mitochondrial hexokinases. Mol. Cell. Biol. 24: 730-740.

42. Rathmell JC, Fox CJ, Plas DR, Hammerman PS, Cinalli RM and Thompson CB (2003) Akt-directed glucose metabolism can prevent Bax conformation change and promote growth factor-independent survival. Mol. Cell. Biol. 23: 7315-7328.

43. Sbarra A and Karnovsky M (1959) The biochemical basis of phagocytosis. I. Metabolic changes during ingestion of particles by polymorphonuclear leukocytes. J. Biol. Chem. 234: 1355-1362.

44. Rameh LE, Arvidsson A, Carraway 3rd KL, Couvillon AD, Rathbun G, Crompton A, VanRenterghem B, Czech MP, Ravichandran KS, Burakoff SJ, Wang DS, Chen CS and Cantley LC (1997) A comparative analysis of the phosphoinositide binding specificity of pleckstrin homology domains. J. Biol. Chem. 272: 22059-22066.

45. Moon JJ and Nelson BH (2001) Phosphatidylinositol 3-kinase potentiates, but does not trigger, T cell proliferation mediated by the IL-2 receptor. J. Immunol. 167: 2714-2723

46. Edinger AL and Thompson CB (2002) Akt maintains cell size and survival by increasing mTOR-dependent nutrient uptake. Mol. Biol. Cell 13: 2276-2288.

47. Zhao JJ, Gjoerup OV, Subramanian RR, Cheng Y, Chen W, Roberts TM and Hahn WC (2003) Human mammary epithelial cell transformation through the activation of phosphatidylinositol 3-kinase. Cancer Cell 3: 483-495.

48. Shim H, Chun YS, Lewis BC and Dang CV (1998) A unique glucose-dependent apoptotic pathway induced by c-Myc. Proc. Natl. Acad. Sci. USA 95: 1511-1516. 
49. Le Goffe C, Vallette G, Jarry A, Bou-Hanna C and Laboisse CL (1999) The in vitro manipulation of carbohydrate metabolism: a new strategy for deciphering the cellular defence mechanisms against nitric oxide attack. Biochem. J. 344 (Part 3): 643-648.

50. Lee MG and Pedersen PL (2003) Glucose metabolism in cancer: importance of transcription factor-DNA interactions within a short segment of the proximal region og the type II hexokinase promoter. J. Biol. Chem. 278: 41047-41058.

51. Gosmain $Y$, Dif N, Berbe V, Loizon E, Rieusset J, Vidal $H$ and Lefai $E$ (2005) Regulation of SREBP-1 expression and transcriptional action on HKII and FAS genes during fasting and refeeding in rat tissues. J. Lipid Res. 46: 697-705.
52. Pozuelo Rubio M, Peggie M, Wong BH, Morrice N and MacKintosh C (2003) 14-3-3S regulate fructose-2,6-bisphosphate levels by binding to PKBphosphorylated cardiac fructose-2,6-bisphosphate kinase/phosphatase. EMBO J. 22: 3514-3523.

53. Carrillo JJ, Ibares B, Esteban-Gamboa A and Feliu JE (2001) Involvement of both phosphatidylinositol 3-kinase and p44/p42 mitogen-activated protein kinase pathways in the short-term regulation of pyruvate kinase $L$ by insulin. Endocrinology 142: 1057-1064.

54. Hobbs S, Jitrapakdee S and Wallace JC (1998) Development of a bicistronic vector driven by the human polypeptide chain elongation factor 1alpha promoter for creation of stable mammalian cell lines that express very high levels of recombinant proteins. Biochem. Biophys. Res. Commun. 252: 368-372.

Supplementary Information accompanies the paper on Cell Death and Differentiation website (http://www.nature.com/cdd) 